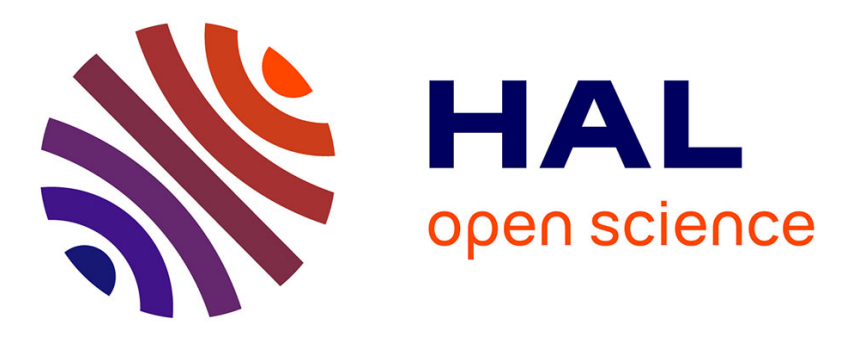

\title{
Mechanical anisotropies and mechanisms of mafic magma ascent in the middle continental crust: The Sondalo magmatic system (N Italy)
}

Benoît Petri, Etienne Skrzypek, Geoffroy Mohn, Tsvetomila Mateeva, Philippe Robion, Karel Schulmann, Gianreto Manatschal, Othmar Müntener

\section{To cite this version:}

Benoît Petri, Etienne Skrzypek, Geoffroy Mohn, Tsvetomila Mateeva, Philippe Robion, et al.. Mechanical anisotropies and mechanisms of mafic magma ascent in the middle continental crust: The Sondalo magmatic system (N Italy). Geological Society of America Bulletin, 2018, 130 (1-2), pp.331 - 352. 10.1130/B31693.1. hal-01670458

\section{HAL Id: hal-01670458 https://hal.science/hal-01670458}

Submitted on 12 Apr 2021

HAL is a multi-disciplinary open access archive for the deposit and dissemination of scientific research documents, whether they are published or not. The documents may come from teaching and research institutions in France or abroad, or from public or private research centers.
L'archive ouverte pluridisciplinaire HAL, est destinée au dépôt et à la diffusion de documents scientifiques de niveau recherche, publiés ou non, émanant des établissements d'enseignement et de recherche français ou étrangers, des laboratoires publics ou privés. 
Mechanical anisotropies and mechanisms of mafic magma ascent in the middle continental crust: the Sondalo magmatic system (N Italy)

Benoît PETRI ${ }^{1,2}$, Etienne SKRZYPEK ${ }^{3}$, Geoffroy MOHN ${ }^{4}$, Tsvetomila MATEEVA ${ }^{5}$, Philippe ROBION ${ }^{4}$, Karel SCHULMANN ${ }^{1,6}$, Gianreto MANATSCHAL ${ }^{1}$, Othmar MÜNTENER ${ }^{2}$

${ }^{1}$ Ecole et Observatoire des Sciences de la Terre, Institut de Physique du Globe de Strasbourg - CNRS UMR7516, Université de Strasbourg, 1 rue Blessig, F-67084, Strasbourg Cedex, France

${ }^{2}$ Institut des sciences de la Terre, Université de Lausanne, 1015 Lausanne, Switzerland

${ }^{3}$ Department of Geology and Mineralogy, Graduate School of Science, Kyoto University,

Kitashirakawa Oiwake-cho, Sakyo-ku, 606-8502 Kyoto, Japan

${ }^{4}$ Département Géosciences et Environnement, Université de Cergy-Pontoise, 5, mail Gay

Lussac, Neuville-sur-Oise, 95031 Cergy-Pontoise Cedex

${ }^{5}$ Department of Earth and Ocean Sciences, University of Liverpool, Liverpool L69 3BX,

United Kingdom

${ }^{6}$ Center for Lithospheric Research, Czech Geological Survey, 11821 Praha 1, Czech Republic

Author contact: bpetri@unistra.fr

ORCID Petri: 0000-0001-7142-0406

ORCID Mohn: /

ORCID Skrzypek: /

ORCID Mateeva: 0000-0002-6155-8687

ORCID Robion: /

ORCID Müntener: 0000-0002-7771-4381

ORCID Schulmann: 0000-0002-5814-9161

ORCID Manatschal: 0000-0003-3834-2033

\section{REFERENCE}

Petri B., Skrzypek E., Mohn G., Mateeva Ts., Robion Ph., Schulmann K., Manatschal G., Müntener O., 2018. Mechanical anisotropies and mechanisms of mafic magma ascent in the middle continental crust: the Sondalo magmatic system (N Italy). GSA Bulletin, 130(1-2), 331352. DOI:10.1130/B31693.1 


\section{ABSTRACT}

Magma transfer between lower and upper continental crust is a fundamental process linking the dominantly mafic composition of the lower crust with the more felsic composition of the upper crust. We explore the mechanisms of mafic magma ascent and emplacement in the middle crust by studying a mid-crustal gabbroic to dioritic magmatic system (Sondalo complex, Eastern Central Alps, N Italy). We characterize the structure and Anisotropy of Magnetic Susceptibility (AMS) fabric of concentric gabbroic to dioritic intrusions. The significance of AMS fabrics is discussed using Anisotropy of Anhysteretic Remanent Magnetization (AARM) and Crystallographic Preferred Orientation (CPO) data acquired on different test sites. The magmatic and magnetic fabrics of the pluton were acquired during its emplacement in the Permian and were not subsequently tilted: the fabrics are essentially vertical, indicating vertical magma transfer through the crust with a two-phase intrusion history. (1) The concordant orientation between the magmatic foliation and the host-rock xenoliths in the center of the pluton suggest that the first magma ascent phase occurred along pathways subparallel to the vertical fabric of the host metasedimentary rocks. (2) The second magma ascent phase was controlled by a change in the rheology of the host-rock and the mafic magma. Heat dissipation to the contact aureole induced partial melting, thereby lowering the mechanical strength of the host-rocks, whereas the viscosity of the mafic magma increased due to cooling and associated fractional crystallization. This caused an en-masse rise of the pluton resulting in the formation of a structural aureole, i.e. a vertical foliation in the contact aureole and a weaker but concordant magmatic foliation at the rim of the pluton. This ascent phase accounts for the $P-T$ evolution recorded by metasedimentary rocks in the contact aureole of the pluton.

\section{KEY WORDS AND SHORT TITLE}

Keywords: Ascent mechanism; Gabbro; Mid-crustal intrusion; AMS; Permian magmatism.

Short title: Mid-crustal gabbro emplacement.

\section{INTRODUCTION}

The ascent mechanisms of magma through the continental crust remain a long standing controversy. The pathways of intermediate to felsic magmas can be traced through the crust: magma is generally sourced in the lower crust and rises through mid-crustal sheeted conduits (Miller and Paterson, 2001; Mahan et al., 2003) up to the amalgamation of upper-crustal batholiths and eventually volcanic structures (e.g. Sawyer et al., 2011). Migration is explained by the lower density of intermediate to felsic melts with respect to the surrounding continental crust and by tectonic activity (Vigneresse and Clemens, 2000). By contrast, most mafic magmas pond at the base of the lower crust and form underplated sill complexes as a consequence of density and rheological barriers (Huppert and Sparks, 1988; Voshage et al., 1990; Rudnick and Fountain, 1995; Gerya and Burg, 2007). In upper crustal levels, mafic magmatic rocks range from small-scale sill complexes and dike swarms to massive flood basalts (e.g. Coffin and Eldholm, 1994).

Being tectonically assisted or not, magma transfer and emplacement within the crust can be achieved in several ways (e.g. Brown, 1994). For granitic magmas, three end-member mechanisms were proposed (e.g. Paterson and Miller, 1998; Petford et al., 2000): (1) diking 
where magma flows in pathways which opened by elastic cracking of the host-rock (fractures; e.g. Lister and Kerr, 1991; Clemens and Mawer, 1992), (2) diapirism where the en-masse displacement of buoyant magma is accommodated by ductile deformation in the host-rock (the material transfer process of Paterson and Fowler Jr, 1993; Ramberg, 1981), and (3) pervasive flow which is expressed on a meso-scale by the formation of magma sheets along the host-rock anisotropy (foliation, bedding; Collins and Sawyer, 1996; Weinberg, 1999), and on a microscale by flow along grain boundaries (e.g. Scott and Stevenson, 1986; Hasalová et al., 2011). However, most of these mechanisms are based on the physical properties of felsic melts, while the transfer and emplacement of mafic magmas through and in the crust are less well constrained.

The viability of diapirism is still debated for granitic magma (see e.g. Brown, 2007), but mafic diapirs are thought not to exist in the continental crust as they are expected to be drained by dikes at early stages of their formation (Weinberg, 1996). Fracture-controlled ascent will produce either dikes or sills depending on the structural relation with the host-rock anisotropy, but needs fast ascent in order to avoid freezing of the magma (Petford et al., 1993; Annen and Sparks, 2002; Menand, 2011). Finally, the pervasive flow mechanism implies that the host-rock temperature lies close to, or above the solidus temperature of the rising melt. For mafic magmas, these conditions are achieved in high temperature settings $\left(>1000^{\circ} \mathrm{C}\right)$ such as in Earth's upper mantle (e.g. McKenzie, 1984; Müntener and Piccardo, 2003) or a pre-existing channel of crystal mush (e.g. Jagoutz et al., 2006; Solano et al., 2014). In any case, several ascent mechanisms may be competing and the dominant mechanism may change through space and time (e.g. Weinberg, 1996). Since the different ascent mechanisms are to some degree controlled by the host-rock composition and structure, constraining the evolution of both the host-rock and intrusive rocks is mandatory to identify the dominant process (Paterson et al., 1991).

The Variscan basement of Central Europe was intruded by numerous mafic and granitic plutons during the Early Permian (see Fig. 1A; Spalla et al., 2014; Petri et al., 2017). However, only the lower-crustal mafic intrusions exposed in the Ivrea zone (Southern Alps) were studied in terms of emplacement dynamics/mechanisms and served to propose two intrusion models. On the one hand, the "gabbro glacier" model of Quick et al. $(1992,1994)$, inspired by magmatic processes active at mid-ocean ridges, inferred continuous replenishment of a magmatic lens at the top of the gabbro. In this model, the mafic body grows by cumulate formation and synmagmatic tectonic extension. On the other hand, Rutter et al. (1993) developed a model involving the emplacement of successive sub-horizontal sills along the host rock foliation. In this model, the mafic body inflates due to locking at the tips of the sill during continuous injection of mafic magma from the mantle. With the exception of centimeter scale veins in shear zones at the top of the gabbro (Handy and Streit, 1999), little remains known about how upper crustal magmatic systems are fed.

The Sondalo gabbroic complex (N Italy) is a mid-crustal mafic pluton; it intruded the Austroalpine Campo unit during Permian times at a depth of 15 to $20 \mathrm{~km}$ (4-6 kbar; Tribuzio et al., 1999; Braga et al., 2001, 2003; Petri et al., 2016). In the Campo unit, the Alpine deformation and metamorphic overprint is generally weak and mostly localized in discrete shear zones located along its margin (Fig. 1B; Schmid and Haas, 1989; Gazzola et al., 2000; Meier, 2003; Viola et al., 2003). In addition, the tectono-thermal evolution of metasedimentary rocks, which surround the Sondalo gabbro, was recently deciphered (Petri et al., 2016). Therefore, the 
Sondalo gabbro represents an ideal target to constrain the structure and emplacement dynamics of a Permian mid-crustal mafic pluton.

In this contribution, we (1) document the structure of a mid-crustal mafic pluton and (2) discuss the ascent mechanism(s) through the continental crust considering the role and behavior of the host-rock during magmatism. While the structure of the host-rock is determined by field mapping, that of the pluton is investigated by combining field mapping with Anisotropy of Magnetic Susceptibility (AMS) data especially in rocks where the magmatic fabric is poorly visible. AMS data are compared to Anisotropy of Anhysteretic Remanence Magnetization (AARM) measurements as well as Crystallographic Preferred Orientation (CPO) patterns for pyroxene, amphibole and ilmenite for different test sites. These results complement our understanding of the magmatic systems associated with Permian post-orogenic extension in the Alps.

\section{GEOLOGICAL SETTING}

The study area is located in the Campo unit, SE Switzerland and N Italy (Fig. 1), which preserves a polyphase tectonic history spanning the Carboniferous Variscan orogeny, the Permian post-orogenic extension, the Jurassic rifting and the Alpine convergence.

The Jurassic and Alpine deformation and metamorphic overprint remained weak and mostly localized along the margin of the unit (Fig. 1B; Schmid and Haas, 1989; Gazzola et al., 2000): to the North, the Campo unit is overthrust by the Filladi di Bormio phyllites while to the South, pervasive deformation related to the Insubric line is reported (Gazzola et al., 2000; Meier, 2003; Viola et al., 2003). The Campo unit is separated from the overlying Grosina orthogneiss unit by the sub-horizontal Eita shear zone, inferred to be Jurassic in age and only weakly reactivated during Alpine compression (Fig. 2A, Meier, 2003; Mohn et al., 2012). This particular configuration explains the relatively minor Jurassic and Alpine deformation and metamorphic overprint in the center of the unit (Fig. 1B), enabling to access the pre-Mesozoic history of the Campo unit (e.g. Hoinkes and Thöni, 1993).

The Campo unit is made of Ordovician sediments (Bergomi and Boriani, 2012) affected by amphibolite-facies metamorphism (Meier, 2003; Petri et al., 2016). This unit was intruded during the Permian by numerous dioritic to granodioritic plutons and notably by the Sondalo gabbroic complex (Del Moro and Notarpietro, 1987; Tribuzio et al., 1999; Gazzola et al., 2000; Mair and Schuster, 2003).

\subsection{Structure and petrology of the Campo unit}

The metasedimentary Campo unit represents the host-rock of the Sondalo gabbro, with a $P-T-d$ evolution described in detail by Petri et al. (2016). Its structural succession involves three deformation events. The first visible fabric, both at a macroscopic and microscopic scale, is a NE-SW trending steep foliation S1 (not shown on Fig. 2A). S1 is affected by open to isoclinal upright $\mathrm{F} 2$ folds with steeply plunging and steep NW-SE trending axial planes, leading in most places to almost complete transposition of the S1 fabric into a NW-SE trending S2 planar fabric (Fig. 2AB). This S2 foliation is crosscut by weakly deformed to undeformed Permian pegmatites (Fig. 3A) and is often preserved in metapelitic septa within the Sondalo gabbro (Figs 2A and 3C). The S2 planar fabric is transposed into a S3 foliation parallel to the margin of the pluton and moderately dipping away from the pluton (Figs $2 \mathrm{~A}$ and $3 \mathrm{~B}$ ). This zone 
of fabric transposition forms a 1-2 km wide structural aureole, which separates the homogeneous structure of the pluton core from the $\mathrm{S} 2$ foliated host-rock.

The metasediments of the Campo unit consist essentially of Grt-St mica schist and paragneiss indicating a prograde path reaching amphibolite-facies conditions of $6 \mathrm{kbar} / 600^{\circ} \mathrm{C}$ during the formation of $\mathrm{S} 1$. This foliation is pervasively overprinted by a NE trending subvertical S2 fabric associated with a Ms-Bt-Sil paragenesis and formed at around $6 \mathrm{kbar} / 650^{\circ} \mathrm{C}$ (Figs $2 \mathrm{AB}$ and $3 \mathrm{~A}$ ). This $\mathrm{S} 2$ fabric represents the main structure observed in the Campo unit and is also found in metapelitic xenoliths (slices up to a few hundred meters in length) in the core of the Sondalo gabbro (Fig. 3C). Subsequent heating in the Campo unit is indicated by regional static crystallization of cordierite and andalusite porphyroblasts.

In the narrow (500-700 m thick) contact aureole, a steeply to moderately dipping S3 fabric is developed all around the pluton (Figs $2 \mathrm{AB}$ and $3 \mathrm{~B}$ ). From the host-rock to the core of the intrusion, increasing metamorphism leads to the transformation of mica schist into Grt-SilCrd-Spl granulite equilibrated at $5.5 \mathrm{kbar} / 930^{\circ} \mathrm{C}$. In the contact aureole, the S3 foliation is associated with the formation of migmatites with Grt-Sil-Bt melanosomes. During D3, migmatites record a decompression from $6 \mathrm{kbar} / 750-800^{\circ} \mathrm{C}$ to $P<4.5 \mathrm{kbar}$. The presence of pre-D3 leucosomes (Fig. 3B) indicates that the contact metamorphism and associated partial melting of the metasedimentary host-rock had already occurred before the development of S3.

\subsection{The Sondalo gabbroic complex}

The Sondalo gabbro is a $40 \mathrm{~km}^{2}$ pluton exposed in the N-S oriented Adda Valley (Fig. 2A). The pluton is concentrically zoned and composed of Ol-gabbro in the Central Zone (CZ), gabbro in the Intermediate Zone (IZ) and diorite to granodiorite in a Border Zone (BZ) of a variable width (Campiglio and Potenza, 1964, 1966, 1967; Koenig, 1964). The contacts between the different zones are rarely visible. All different facies are thought to be derived from a tholeiitic parental liquid, which was differentiated through fractional crystallization and affected by crustal assimilation (Tribuzio et al., 1999).

Sm-Nd mineral-isochrons on troctolite and norite samples gave ages of $300 \pm 12$ and $280 \pm 10 \mathrm{Ma}$, respectively. $\mathrm{Rb}-\mathrm{Sr}$ isochron ages for the same samples are respectively $266 \pm$ 10 and $269 \pm 16 \mathrm{Ma}$ (Tribuzio et al., 1999). U-Pb zircon data for two diorite samples from the BZ gave concordant ages of $c a$. $270 \mathrm{Ma}$ (Bachmann and Grauert, 1981). U-Pb zircon dating on five magmatic and metamorphic samples collected across the pluton provides consistent ages indicating magma emplacement and HT-metamorphism from $289 \pm 4$ Ma to $285 \pm 6 \mathrm{Ma}$ (Petri et al., 2017). Trace elements in zircon from magmatic rocks point to a progressive mixing of mantle-derived melts with crustal ones which probably derived from partial melting of the surrounding metasediments. Rare trachytic dikes dated at $32 \pm 1$ Ma cross-cut the complex $(\mathrm{K}-$ Ar on ground-mass, Bianchi Potenza et al., 1985).

\section{PETROGRAPHY AND MAGMATIC STRUCTURES OF THE SONDALO GABBRO}

\subsection{Petrography}

The $\mathrm{CZ}$ and IZ of the gabbroic complex consist of Ol-gabbro, and gabbro to norite (Fig. 4GH) mainly composed of euhedral to subhedral plagioclase, olivine, clinopyroxene and orthopyroxene, with a higher amount of olivine in Ol-gabbros. Plagioclase is labradoritic and 
often zoned with higher anorthite content in the core. Olivine is often replaced by pseudomorphs of talc and magnetite. Orthopyroxene is euhedral to subhedral while clinopyroxene is poikilitic; both are locally rimmed by red-brown $\mathrm{Ti}$-pargasite with a poikilitic texture. Both pyroxene and pargasite are in places transformed into brown-green hornblende. Biotite is a rare interstitial mineral in (olivine-) gabbro and norite. In the gabbro, ilmenite is the main opaque phase with minor poikilitic Fe-sulfides (pyrrhotite) and magnetite. Ilmenite and magnetite can be intergrown and occur in between plagioclase grains (Fig. 4K). Numerous magnetite and ilmenite lamellae are frequently exsolved from pyroxene crystals (with up to 1 wt. $\%$ of $\mathrm{TiO}_{2}$; Tribuzio et al., 1999) along their cleavage planes (Fig. 4L). Rutile is found as inclusion in pyroxene, not as exsolution but potentially as retrogressed ilmenite (Fig. 4L).

In the BZ, diorite and granodiorite have a hypidiomorphic structure with euhedral to subhedral plagioclase and green-brown hornblende (Fig. 4I). Zoned plagioclase has a labradorite core and an andesine rim. Hornblende may contain inclusions of clino- and orthopyroxene. Interstitial quartz is locally frequent. Opaque minerals are mostly ilmenite with rare pyrrhotite and magnetite, all having the same textures as in Ol-gabbro.

\subsection{Magmatic fabric}

Ol-gabbro, gabbro and diorite are medium-grained and show a weakly to strongly developed macroscopic fabric ( $\mathrm{Sm} 1)$. The fabric is defined by the shape-preferred orientation of euhedral to subhedral and elongated plagioclase, pyroxene and amphibole (Fig. 4CDEGI). This foliation is steeply dipping to the North or South (Fig. 2AB). Locally, fine-grained gabbro rhythmically alternates with coarser-grained one (Fig. 4AB). Rare pyroxenite layers are parallel to the sub-vertical foliation (Fig. 4C). Under the microscope, pyroxene is aligned parallel to the layers (Fig. 4G) and is locally included in poikilitic plagioclase, indicating mineral sorting during magma flow (Tobisch et al., 1997). The absence of solid-state deformation (dynamic recrystallization or pressure shadows around magmatic minerals) indicates that the mineral foliation is of magmatic origin (for criteria, see e.g. Paterson et al., 1989; Vernon, 2000). Only close to the Eita shear zone, recrystallization of magmatic minerals attests to solid-state deformation at greenschist-facies conditions.

In the BZ, the magmatic foliation (Sm2) locally lies at high angle with respect to the principal magmatic fabric of the pluton (Sm1; Fig. 2A). The fabric is characterized by the shapepreferred orientation of magmatic plagioclase and amphibole, and is roughly parallel to the pluton margin and to the S3 foliation in the contact aureole. In the transition zone between the two fabrics, no evidence for magmatic fabric transposition can be detected on the outcrop scale, as rocks in this area are apparently isotropic. Moreover, folding of the magmatic foliation or cumulate layers is not visible. Under the microscope, the magmatic foliation is poorly developed, with plagioclase and ferromagnesian minerals forming a "mesh" structure (Fig. 4J), indicating that the transposition of Sm1 into Sm2 occurred at the grain scale.

Late-stage magma accumulation formed unfoliated patchy pockets which cross cut the main magmatic foliation (Fig. 4E). Syn-magmatic mafic dikes cross cut the weakly to well foliated gabbro, sometimes with a sharp contact (Fig. 4F). Both usually display coarse-grained textures with up to $5 \mathrm{~cm}$ long plagioclase and hornblende crystals. Subhedral plagioclase defines a very weak shape-preferred orientation, whereas hornblende is poikilitic and locally 
includes clinopyroxene. In the BZ, magma mingling between a felsic and a more mafic magma is indicated by lobate and chilled margins.

\section{METHODOLOGIES}

In contrast to granitic rocks and migmatites, the application of Anisotropy of Magnetic Susceptibility (AMS) analysis to mafic rocks in order to estimate the rock fabric is not straightforward. Such rock types may often have inverse to abnormal (intermediate) magnetic fabrics with respect to the petrographic fabric (petrofabric; e.g. Geoffroy et al., 2002). First, in mafic rocks, the AMS may be controlled by paramagnetic minerals such as pyroxene and amphibole; both have a variable long axis $\left(K_{l}\right)$ orientation that can lie at high angle to the crystallographic $c$-axis (e.g. Borradaile and Jackson, 2010; Rochette et al., 1999). Second, mineral orientations may sometimes differ from that of the magmatic flow with e.g. mineral imbrications or local variations in the magma flow (Cañón-Tapia and Chávez-Álvarez, 2004). Pyroxene is known to host magnetite inclusions or exsolutions (Lagroix and Borradaile, 2000; Renne et al., 2002); these can sometimes mimic and enhance the magnetic signal of pyroxene if they grow along the $c$-axis of the host mineral (e.g. Yaouancq and MacLeod, 2000), but can also induce a third perturbation type if they grow randomly or along structures independent of the rock fabric (Rochette, 1987; Clark and Tonkin, 1994; Rochette et al., 1999). A fourth perturbation may be due to magnetite itself. Depending on its grain size, magnetite can be either single- or multi-domainal and present intrinsic axis permutations (Rochette et al., 1992). Despite these caveats, the AMS method was successfully applied in the past to mafic rocks (Pearce and Fueten, 1989; Richter et al., 1996; Yaouancq and MacLeod, 2000). Therefore, in order to carefully link magnetic fabrics to petrofabrics, we coupled AMS to Anisotropy of Anhysteretic Remanent Magnetization (AARM). Finally, as a magnetic fabric is often sourced in the Crystallographic Preferred Orientation (CPO) of magnetic phases composing the rock, $\mathrm{CPO}$ analysis facilitate linking magnetic fabrics to the petrofabrics. A short description of the applied methods is presented below; detailed datasets, methodologies, analytical conditions and parameters descriptions are reported in the supplementary material.

\subsection{AMS Measurements}

Samples were collected using a portable drilling machine at the 67 sites indicated on Fig. 2C. Site locations were selected with the aim of regularly covering the exposed pluton. At least 2 cores per site were collected, with a minimum of 10 standard specimens $(25 \mathrm{~mm}$ in diameter and $22.5 \mathrm{~mm}$ in height) and oriented with a magnetic compass. AMS was characterized for all samples whereas magnetic mineralogy was determined for one specimen per site.

The AMS was measured on all available specimens with a MFK1-A Kappabridge (AGICO, Inc.) operating in low field $\left(200 \mathrm{~A}^{-\mathrm{m}^{-1}}\right)$ at the University of Strasbourg. Raw data are reported as supplementary material. The magnetic susceptibility $K_{m}$ is usually controlled by the relative proportion of diamagnetic, paramagnetic and ferromagnetic minerals. Rocks with $K_{m}$ on the order of $10^{-4}$ SI have an AMS signal carried by paramagnetic minerals (e.g. pyroxene and amphibole with intrinsic $K_{m}=0.5-510-6 \mathrm{~m}^{3} \cdot \mathrm{kg}^{-1}$; Hrouda, 1982; Rochette et al., 1999; Biedermann, Koch, et al., 2015; Biedermann, Pettke, et al., 2015) with a minor contribution of ferromagnetic minerals whereas rocks with susceptibilities around $10^{-3}$ SI likely contain 
ferromagnetic minerals (Hrouda and Kahan, 1991; Rochette et al., 1992). In order to qualitatively constrain the variability of AMS fabric due to the variability of ferromagnetic (s.l.) minerals, we identified the magnetic mineralogy by investigating coercivity-unblocking temperature spectra of ferromagnetic minerals (following the method of Lowrie, 1990) using magnetic fields of $0.1,0.5$ and $1.4 \mathrm{~T}$ (see supplementary material for details).

\subsection{AARM Measurements}

In order to characterize the fabric of ferromagnetic minerals, we measured AARM data from 7 specimens per site out of 15 sites defining an E-W profile across the pluton (location on Fig. 2C) with the aim of detecting potential intermediate to normal magnetic fabrics with respect to the petrofabric (e.g. Rochette et al., 1999). AARM data were acquired at the University of Cergy-Pontoise using a JR6-A spinner magnetometer (AGICO, Inc.) on samples previously demagnetized with a LDA-3F tumbling demagnetizer (AGICO, Inc.) and magnetized in the direction of interest with an AMU-1A magnetizer.

\subsection{CPO Measurements}

The CPO of orthopyroxene, clinopyroxene, hornblende and ilmenite was characterized by Electron Back-Scattered Diffraction (EBSD) analysis of 6 specimens from 6 sites located on an E-W, core-to-rim transect across the pluton (location on Fig. 2C) using a Tescan Mira GMU3 at the Czech Geological Survey, Prague. Data were processed using MTEX version 4.2.1 (Bachmann et al., 2010) and are presented in the geographic reference frame together with AMS and macroscopic structures measured at the same sites (Fig. 12). Pole figure strength are estimated by the $\mathrm{J}$-index ( $\mathrm{pfJ}=1$ if randomly oriented; $\mathrm{pfJ}=\infty$ if perfectly oriented; Bunge, 1982) and $\mathrm{M}$-index (pfM=0 if randomly oriented; $\mathrm{pfM}=1$ if perfectly oriented; Skemer et al., 2005); pole figure symmetry are characterized by the $\mathrm{K}$ index $(0<\mathrm{K}<1$ for oblate ellipsoid; $1<\mathrm{K}<\infty$ for prolate ellipsoid; Woodcock, 1977) and the LS-index ( $\mathrm{LS}=0$ for oblate ellipsoid; LS=1 for prolate ellipsoid; Ulrich and Mainprice, 2005; see supplementary material and Mainprice et al., 2014 for details).

\section{ANISOTROPY OF MAGNETIC SUSCEPTIBILITY RESULTS}

\subsection{Magnetic mineralogy}

Following the results of stepwise thermal demagnetization 3axes-IRM, three different rock types can be defined according to their variable amounts of ferromagnetic phases. The first group (Fig. 5B) presents a progressive decrease of the magnetization from ambient temperature to an unblocking temperature around $580^{\circ} \mathrm{C}$, pointing to the presence of nearly pure magnetite mainly revealed by the low coercivity axis $M(x)$ (titanomagnetite with low Ti-content; Lattard et al., 2006). The second group (Fig. 5C) presents a sharp decrease of the signal from the beginning of the experiment until $350^{\circ} \mathrm{C}$, followed by a progressive decrease until $580^{\circ} \mathrm{C}$. This points to a two-phase composition. With an unblocking temperature around $350^{\circ} \mathrm{C}$, the first phase could either be titanomagnetite or pyrrhotite (iron-sulfide), but the low magnetization of the medium coercivity axis $M(y)$ values indicates the presence of a lower coercivity phase that can preferentially be a low coercivity pyrrhotite or a titanomagnetite. The second phase of higher unblocking temperature around $580^{\circ} \mathrm{C}$ can be magnetite. The third group presents a sharp 
decrease from the beginning of the experiment until $350^{\circ} \mathrm{C}$ mainly carried by the low coercivity axis $M(x)$ indicating a low coercivity pyrrhotite or titanomagnetite (Fig. 5D). In rare cases, the signal of the medium coercivity axis $M(y)$ indicates the presence of a higher coercivity pyrrhotite (Fig. 5E). These 3axes-IRM results do not allow making the distinction between pyrrhotite and titanomagnetite, but as pyrrhotite was observed in thin section (see petrographic description), we favor the presence of pyrrhotite while the occurrence of minor titanomagnetite is not excluded.

\subsection{Bulk magnetic susceptibility}

The bulk magnetic susceptibilities of rocks from the Sondalo gabbroic complex range from 448 up to $3540^{*} 10^{-6}$ SI (Fig. 6A) with most values below $10^{-3}$ SI. Such a wide range of values indicates a mixed contribution of paramagnetic and ferromagnetic minerals to the AMS signal. For the rare values above $10^{-3} \mathrm{SI}$, the signal is assumed to be carried essentially by ferromagnetic minerals. Despite the textural heterogeneity of magmatic rocks, the bulk susceptibility is usually consistent at the outcrop scale (Fig. 8A); rare, highly variable values, indicate that ferromagnetic minerals may not be homogeneously distributed (e.g. site 7).

In a map view, the highest susceptibility values $\left(K_{m}>1.5^{*} 10^{-3} \mathrm{SI}\right)$ lie close to the Olgabbro core (Fig. 7). In contrast, no specific trend is observed towards the margin of the complex and $K_{m}$ values are generally lower than $10^{-3} \mathrm{SI}$.

The distribution of the bulk susceptibilities over the pluton (Fig. 7A) agrees generally well with the three mineralogical groups (Fig. 5A). Low susceptibility samples usually do not contain magnetite, whereas high susceptibility samples do. This is not the case for only few sites (e.g. sites 25, 29 and 30), which is probably due to the strong difference in the distribution of ferromagnetic phases in these samples.

\subsection{Magnetic fabric parameters}

The magnetic anisotropy $P j$ (see definition in supplementary material) ranges from 1.006 up to 1.151 with a mean value around 1.037 . The spread of the anisotropy increases progressively with increasing $K_{m}$ values; it reaches a maximum of 1.11 for $K_{m}$ values above $10^{-}$ ${ }^{3}$ SI (Fig. 6B), typically observed for magnetite- and pyrrhotite-bearing samples (Rochette, 1987). At the scale of the outcrop or sample, $P j$ is quite low but seems to be constant (Fig. $8 \mathrm{AB})$. Average values for texturally different cores from the same outcrop indicate that in general, specimens presenting a macroscopic mineral foliation are more anisotropic and yield higher $P j$ values (Fig. 8A). $P j$ is not correlated with the magnetic mineralogy (Fig. 6BF).

The analyzed sites have a shape parameter $T$ spanning a linear to planar geometry, with an average value of 0.055 (Fig. 6C). $T$ is independent of the magnetic mineralogy (Fig. 6DF). Only rare sites are strictly linear whereas many more sites are strictly planar (Fig. 6CDEF), but no evident spatial trend can be recognized (Fig. 7C). $T$ does not seem to be correlated with the bulk susceptibility of rocks but tends to be more plano-linear for high $P j$ values (Fig. 6CDEF). $T$ can vary from one extreme to the other in specimens from the same core especially for cores with coarse-grained textures (Fig. 8B). 


\subsection{Magnetic foliation and lineation}

The magnetic foliation corresponds to the plane containing the longest $\left(K_{l}\right)$ and intermediate $\left(K_{2}\right)$ axes of the AMS ellipsoid. The pole of the magnetic foliation corresponds to the shortest axis $\left(K_{3}\right)$, and the magnetic lineation corresponds to the orientation of the longest axis $\left(K_{1}\right)$.

At the outcrop scale, the orientation of the main susceptibility axis of the magnetic ellipsoid is rather constant, except for coarse-grained specimens. The mean declination and mean inclination of $K_{1}$ and $K_{3}$ are usually similar between cores with different textures. Exceptions are represented by sites 31, 54, 58, 23 and 41 where variations of $K_{1}$ orientation between cores from the same outcrop but having different textures reach more than $30^{\circ}$ for inclination and up to $90^{\circ}$ for declination (Fig. 8C). For such cores, $T$-values indicate that the shape of the AMS ellipsoid is plano-linear to planar and therefore $K_{1}$ orientation is not representative (Fig. 8C). Conversely, the orientation of the short magnetic axis $\left(K_{3}\right)$ is highly variable for a few sites that are plano-linear to linear, i.e. where the $K_{3}$ orientation is meaningless (Fig. 8D).

At the scale of the pluton, the orientation of the AMS ellipsoid is rather constant in the CZ and IZ (Fig. 9). The magnetic foliation for sites with planar and planar to plano-linear magnetic ellipsoids is ENE-WSW striking and steeply dips to the North or South (Figs 9a and $10 \mathrm{~A})$. For sites with linear and linear to plano-linear ellipsoids, $K_{l}$ shows a well-defined subvertical maximum (Fig.9B). A few sites close to metapelitic xenoliths have slightly shifted major susceptibility axes with respect to surrounding sites (e.g. sites 35 and 36).

Towards the margin of the pluton, the orientation of $K_{1}$ and $K_{3}$ becomes different from that in the pluton core, although the latter is still locally preserved (e.g. site 49). In the transition zone towards the West, the poorly defined foliation (linear magnetic ellipsoid) is moderately dipping to the NW and lies at high angle with respect to the foliation in the pluton core. The magnetic lineation moderately plunges to the SW. In the outermost part of the pluton, the AMS ellipsoid is planar and defines a foliation trend which is parallel to the pluton margin and dips steeply to moderately away from the pluton: foliations are dipping to the West in the western BZ (e.g. site 25) and to the E in the eastern BZ (e.g. site 64). Additionally, one outcrop in the West displays a sub-horizontal foliation (site 23). All this group of data in the margin of the pluton defines outlier values in Fig. 10A.

\section{ANISOTROPY OF ANHYSTERETIC REMANENT MAGNETIZATION}

The shape and anisotropy parameters of the AARM ellipsoid ( $T$ and $P j$ values) are rarely similar to those of AMS data. It is the case for low magnetic susceptibility sites, but also for high magnetic susceptibility sites where a strong contribution of ferromagnetic minerals was inferred. This observation is quite common, even in rocks where magnetic fabric is carried solely by ferromagnetic minerals (Hrouda, 2002).

Among the 15 studied sites, 7 sites present a good correlation between AMS and AARM axes (concordant group 1), where $K_{1}, K_{2}$ and $K_{3}$ are lying close to $R_{1}, R_{2}$ and $R_{3}$, respectively (e.g. sites 32 and 9 on Fig. 11). A second group of 5 sites presents scattered AARM data between the different specimens due to a low anisotropy (concordant group 2), but still presents coherent averaged axis orientations between AMS and AARM data (e.g. site 20 on Fig. 11). Finally, 3 sites present well defined AARM axes that lie at high angle with respect to the AMS 
axes (concordant group 3; e.g. site 33 in the eastern BZ on Fig. 11). Despite this discordance, AMS is coherent with the magmatic and metamorphic foliations of the surroundings. At site 33, AARM orientations have sub-vertical $R_{l}$ and sub-horizontal, plunging to the SW $R_{3}$. These axes are similar to those recorded at the nearby site 32 , closer to the border, which has coaxial AMS and AARM axes with a sub-horizontal striking to the SW $K_{3}$. The concordance between AMS and AARM orientation data seems to be independent from the magnetic susceptibility and occurs at high magnetic susceptibility sites where the AMS signal is dominated by ferromagnetic phases.

\section{CRYSTALLOGRAPHIC PREFERRED ORIENTATION}

The relation between crystallographic and AMS axes (Fig. 12 and supplementary figure S9) is shortly summarized hereafter. Orthopyroxene $a$ - and $b$-axes are frequently at low angle with respect to $K_{3}$, whereas the $c$-axis is either distributed along the $K_{1}-K_{2}$ (when oblate AMS ellipsoid) or $K_{1}-K_{3}$ plane (when prolate AMS ellipsoid). Although they show a weak CPO, clinopyroxene $a$ - and $b$-axes are distributed along the $K_{1}-K_{2}$ plane, and $c$-axis preferentially lies close to $K_{3}$. Hornblende $a$ - and $b$-axes are frequently parallel to $K_{3}$ and $K_{2}$, respectively. $C$-axis seems to lie close to $K_{1}$ but is distributed on either the $K_{1}-K_{2}$ (when oblate AMS ellipsoid) or $K_{1}-K_{3}$ plane (when prolate AMS ellipsoid). Ilmenite $c$-axis (tabular, $c$-axis perpendicular to the basal plane) systematically lies at high angle with respect to $K_{1}$, being parallel to $K_{2}$ or $K_{3}$. To summarize, most of the crystallographic orientations may be correlated with the AMS ellipsoid axes; with the exception of clinopyroxene, $c$-axes are similar to $K_{l}$, while $a$ - and $b$-axes are parallel to either $K_{2}$ or $K_{3}$. Opaque minerals (i.e. mostly ilmenite) behave even more consistently with a $c$-axis always parallel to $K_{3}$.

The two samples from the core of the pluton are characterized by a well-developed CPO of orthopyroxene, with $c$-axes defining an ENE-WSW girdle (Fig. 12). Although slightly weaker than for sample 56/2D, the $c$-axis distribution has low K and LS values and defines a foliation which steeply dips to the SSE and lies parallel to both the AMS and macroscopic foliations. Clinopyroxene $a$-axis shows an ill-defined girdle parallel to both the AMS and the macroscopic foliations while $c$-axis defines a sub-horizontal $\mathrm{N}-\mathrm{S}$ striking maximum, with strongly prolate $\mathrm{K}$ and LS parameters.

In the transition zone, the $a$-axis orientation of orthopyroxene in sample 51/2B does not display a clear pattern, as opposed to the sub-horizontal NNE-SSW maximum defined by the $b$-axes. The $c$-axis orientation presents a crossed girdle with a well-developed WNW-ESE striking and steeply dipping primary branch and an ill-defined steeply dipping N-S striking secondary branch (dotted lines in Fig. 12); both branches define a sub-vertical intersection lineation. Hornblende $c$-axis defines a weak girdle while ilmenite $c$-axes indicate two weakly developed sub-horizontal point-maxima striking to the $\mathrm{N}$ or to the $\mathrm{W}$. This dataset indicates the presence of two foliations which strike WNW-ESE and N-S and define a sub-vertical intersection lineation parallel to $K_{l}$. The second sample is characterized by a girdle of orthopyroxene $c$-axes moderately dipping to the SW. Hornblende $c$-axis presents one point maximum shallowly dipping to the NNW and SSE and weakly defining a girdle gently dipping to the SW. Ilmenite $c$-axis orientations depict a strong point maximum gently dipping to the NNE. Altogether, the calculated mean foliation is consistent between orthopyroxene, hornblende and ilmenite, and is moderately dipping to the SW at high angle with respect to the 
AMS foliation. Both K and LS indexes point to a slightly more prolate strain ellipsoid, but still in the oblate range. The $c$-axis maxima for both orthopyroxene and amphibole are close to $K_{l}$.

The two samples of the pluton rim preserve weak but consistent CPO patterns for the different minerals. Hornblende $c$-axis for sample 22/1F are distributed along an ill-defined girdle moderately dipping to the SSE while ilmenite $c$-axis orientations show a point-maxima moderately dipping to the NNW. Both hornblende $c$-axis girdle and ilmenite $c$-axis pointmaxima define a foliation moderately dipping to the SE, parallel to the measured AMS foliation. Similar observations can be drawn for sample 25/2E with a weak hornblende and ilmenite CPO defining a foliation that moderately dips to the $\mathrm{W}$, parallel to both macroscopic and measured AMS foliations. K and LS indexes indicate a slightly oblate strain ellipsoid.

\section{DISCUSSION}

\subsection{Magmatic and magnetic fabrics}

\subsubsection{Significance of magnetic fabrics}

The petrofabrics of rocks from the Sondalo complex are defined by the shape-preferred orientation of plagioclase, orthopyroxene, hornblende and rarely biotite. This fabric is coherent from the outcrop to the thin-section scale, and is considered to be of magmatic origin based on: (1) the presence of sheeted zones with rhythmic layering (Fig. 4AB), (2) the strong shape and crystallographic preferred orientation of euhedral and subhedral crystals with no sub-solidus recrystallization or pressure shadows (Figs 4DI and 12), and (3) the presence of vertical mafic compacted levels with a preferred orientation of mafic minerals (essentially orthopyroxene and hornblende) intergrown with undeformed and randomly oriented poikilitic clinopyroxene and minor plagioclase (Figs 4CG and 12). Minerals were therefore oriented during magma flow due to possible velocity gradients (e.g. Benn and Allard, 1989; Cañón-Tapia and Chávez-Álvarez, 2004) or compaction and extraction of felsic liquids from mafic cumulates (e.g. Higgins, 1991; Nicolas, 1992).

In the Sondalo gabbro, the variation of the magnetic susceptibilities is correlated with both the lithology and magnetic mineralogy. The AMS signal is dominated by ferromagnetic magnetite and pyrrhotite for samples with the highest $K_{m}$ values, whereas both ferromagnetic and paramagnetic (e.g. pyroxene, amphibole) minerals contribute to the signal for samples with the lowest $K_{m}$. The orientation of magnetic foliations is remarkably similar to that of the macroscopic magmatic fabrics (Figs 10 and 12), especially for sites with more oblate AMS ellipsoids. This is due to the alignment in the magmatic foliation (Fig. 4K) of minerals that should have similarities between crystallographic and magnetic axes ( $c$-axis parallel to $K_{l}$ ), typically orthopyroxene (Biedermann, Pettke, et al., 2015) and hornblende (Biedermann, Koch, et al., 2015). Conversely, the weaker CPO pattern defined by clinopyroxene (Fig. 12) may be ascribed to its late-stage crystallization, after the main magmatic flow. Additionally, the generally good concordance between AMS (governed by both para- and ferromagnetic phases) and AARM (solely governed by ferromagnetic phases) indicates that both paramagnetic and ferromagnetic phases are similarly oriented (with the exception of few sites discussed hereafter in section 8.1.2). As a late crystallization of opaque minerals is indicated by zircon trace element compositions (Petri et al., 2017) two scenarios can be drawn. (1) The crystallization of opaque 
minerals (e.g. pyrrhotite with poikilitic texture or small ilmenite elongated grains) occurred along already crystallized and oriented minerals that can form a planar template controlling the growth of ferromagnetic minerals (Fig. 13; Hrouda et al., 1971). As a consequence, ferromagnetic grains will be aligned with the foliation defined by silicate minerals (e.g. as in Fig. 4K; Kratinová et al., 2010). (2) Magnetite formed as exsolutions along lattice anisotropies of pyroxene, typically the [100] and [010] cleavage planes (in a similar position to ilmenite on Fig. 4L). Their size and shape indicate that they are multi-domain magnetite, where AMS is controlled by the shape of the grain (Butler and Banerjee, 1975; Bouchez, 2000; Frandsen et al., 2004). Consequently, the $K_{l}$ axis will be defined by the intersection of [100] and [010] cleavage planes in pyroxene, which is parallel to the crystallographic $c$-axis. Both mechanisms indicate that ferromagnetic grains mimic the orientation of the foliation constituted by silicate minerals (both lattice, cleavage and shape), explaining the high concordance between the petrofabric, the CPO and magnetic fabric orientations (Fig. 13; e.g. Archanjo et al., 1994; Yaouancq and MacLeod, 2000). However, K and LS-parameters inferred from CPO patterns never indicate prolate strain ellipsoids, even in the case of samples with prolate AMS ellipsoids. This discrepancy highlights that AMS parameters do not fully reflect the strain geometry acquired during magma emplacement, probably due to the late/secondary growth of ferromagnetic minerals (Borradaille and Henry, 1997; Kratinová et al., 2010).

\subsubsection{Fabric distribution across the pluton}

In the $\mathrm{CZ}$, the magmatic (Sm1) and magnetic foliations are steeply $\mathrm{N}$ - or S-dipping. These structures are parallel to the elongated metapelitic xenoliths and their internal foliation, and are in continuity with the host-rock planar structure S2 (Figs 2AB and 9). Therefore, we assume that magma flowed vertically along the host (and inherited) metapelitic foliation. In this scenario, the progressive lateral widening of the pluton resulted in the dismembering and assimilation of metasedimentary screens. Additionally, the position of xenoliths in the western part of the pluton, in continuity with the host-rock planar structure S2, indicates that these were not strongly re-oriented during the emplacement of mafic magmas. There, the AMS parameters are highly variable and agree with local variations of the structural trend, suggesting that the primary flow field was deflected around the xenoliths.

In the BZ, both magnetic and magmatic ( $\mathrm{Sm} 2)$ foliations are moderately to steeply dipping with a trend roughly following the margin of the pluton. Notably, the foliations are moderately to steeply E- or W-dipping in both eastern and western BZ. There, shape parameters indicate a planar AMS ellipsoid. These foliations are parallel to the S3 planar structures of the migmatitic contact aureole (Fig. 9A) as well as in some outermost metapelitic xenoliths from the BZ (Giacomini, 1997 in the eastern BZ; Petri et al., 2016 in the western BZ) and are rarely found in metapelitic xenoliths or the pluton in the CZ. Petri et al. (2016) showed that this D3 deformation was active at supra-solidus conditions $\left(4.8-6 \mathrm{kbar} / 725-800^{\circ} \mathrm{C}\right)$. In the western part, one outcrop (site 23) presents a shallow-dipping foliation likely associated to deformation produced by the sub-horizontal Eita shear zone (Meier, 2003; Mohn et al., 2012) rather than syn-magmatic processes.

Two hypotheses can account for the different orientation of Sm1 and Sm2 structures between the $\mathrm{CZ}$ and the BZ. On the one hand, both structures could have been acquired at the same time as a result of different primary magma flow fields in the $\mathrm{CZ}$ and the BZ. On the other 
hand, they could reflect two successive deformation stages that affected the pluton. We present several arguments that support the latter, diachronous hypothesis.

The mesh texture of magmatic rocks in the transition zone may point to partial transposition of the E-W trending foliation (Sm1) into a subsequent N-S trending foliation (Sm2, Figs 4J and 13). The overprinting relationships between the two fabrics seem to be documented in the western margin of the central part, between sites 15 and 52 (Fig. 9A). The presence of two foliations is evidenced by EBSD data in sample 51/2B (and slightly in sample 20/2E) where orthopyroxene $c$-axes define two girdles instead of a point maximum (Fig. 12). The magnetic foliation (moderately dipping to the west) is poorly constrained because of a systematic, prolate AMS ellipsoid, which can result from the superposition of the two magmatic fabrics (Schulmann and Ježek, 2012). On the grain scale, the transposition occurs without kinking or folding of the previous fabric indicating that crystals were individually rotated while being still separated by a liquid fraction (crystal mush). The transposition process and its impact on the AMS ellipsoid and parameters should be similar to that described and modelled by Lehmann et al. (2013). These authors show that the transposition of a magmatic fabric leads to a strong $c$-axis orientation of elongated minerals (e.g. amphibole) and a strong prolate AMS ellipsoid, overcoming the AMS signal of planar minerals (e.g. biotite) that show zone axis patterns. The late and secondary crystallization of ferromagnetic minerals mimics this petrofabric; the ferromagnetic minerals probably have an elongated shape resulting in an overall elongated (linear) AMS ellipsoid.

Such a fabric superposition can also be inferred in sites where AMS and AARM are discordant (concordant group 3). Potentially, this may attest for an inverse magnetic fabric with respect to the petrofabric (Rochette et al., 1999). However, AMS orientations from these sites (e.g. site 33) are coherent with the regional AMS and petrofabrics (i.e. NE-SW trending, steeply dipping foliations; Figs 2 and 9). An alternative explanation can be a misorientation between the paramagnetic and the ferromagnetic phases due to sequential crystallization under different stress fields. While the paramagnetic phases crystallized before and during the formation of the first magmatic foliation ( $\mathrm{Sm} 1$ ), ferromagnetic phases crystallized under a different regime that can be linked to the formation of the second magmatic foliation (Sm2). This is seen in the eastern BZ at sites 32 and 33, site 32 having similar AMS and AARM orientations than AARM for site 33 combined to a prolate AMS ellipsoid typical for fabric superposition.

Syn-magmatic and coarse-grained dikes locally crosscut the main magmatic fabric at high angles. Despite the absence of a clear magmatic fabric for such coarse textures, AMS parameters and orientation of the main susceptibility axis are consistent with the surrounding foliated rocks. This is true except for the $K_{1}$ orientations of planar ellipsoids and the $K_{3}$ orientations of linear ellipsoids (Fig. 8). Therefore we assume that the coarse-grained dikes locally used the host-rock anisotropy or represent late-stage pockets that solidified at the end of the principal magmatic flow event.

\subsection{Emplacement history of the Sondalo gabbroic complex}

\subsubsection{Position of the Sondalo gabbroic complex in the Permian}

We first demonstrate that the orientation of structures described in and around the Sondalo gabbroic complex have not been significantly tilted since the Permian. Due to 
pervasive D3 deformation in the structural aureole and because magmatic fabrics and flow are preserved, we could not use polarity criteria (e.g. Burg, 1991; Wiebe et al., 2006) but present large-scale observations to support the absence of significant tilting of the Campo unit after the emplacement of the Sondalo gabbroic complex.

(1) The pluton is concentrically zoned (Fig. 2) with sub-vertical boundaries between the different lithological zones (Koenig, 1964). This is different to sill complexes emplaced by sub-horizontal flow where more differentiated and buoyant melt concentrates at the (paleo-)roof of the magmatic apparatus (e.g. Solano et al., 2014; Sinigoi et al., 2016);

(2) No specific accumulation of large xenoliths can be seen in the field or in map view (see Fig. 2), although the xenoliths are significantly denser (3.13-3.55) than the surrounding gabbroic rocks (2.7-2.8; Braga et al., 2001);

(3) Contact metamorphism caused by magma emplacement generated a concentric metamorphic zonation (i.e. radially increasing towards the center of the pluton; Petri et al., 2016) but does not present a unidirectional gradient as developed in the Ivrea mafic complex (Demarchi et al., 1998);

(4) $P-T$ conditions are uniform across the Campo unit (Petri et al., 2016), except in localized Alpine shear zones and in contact aureoles around Permian intrusives. Given the widespread Permian imprint documented in the Alps (Schuster and Stüwe, 2008) and the spatial extent of the Campo unit, any significant tilting should have resulted in a regional $P-T$ gradient (e.g. Redler et al., 2012), which is not observed;

(5) The Jurassic Eita shear zone, located at the contact between the Campo and Grosina units, is a sub-horizontal structure along which greenschist-facies assemblages are observed (Mohn et al., 2012). This indicates that the shear zone was already subhorizontally during the Jurassic and that no subsequent tilting affected the study area.

Altogether, these elements suggest that the Sondalo gabbroic complex and most of the Campo unit were not significantly tilted and still preserve their Permian orientation: they are surrounded by only localized, Alpine greenschist-facies structures (Schmid and Haas, 1989; Gazzola et al., 2000; Meier, 2003; Viola et al., 2003). As a consequence, the Sondalo gabbro essentially preserves sub-vertical magmatic foliations with sub-vertical magmatic lineations pointing to sub-vertical magmatic flow (Fig. 9), which is interpreted to reflect the original emplacement geometry of the pluton. This allows us to use structural, metamorphic and geochronological data to develop a two-stage model for mafic magma ascent and emplacement in the middle crust (Fig. 14).

\subsubsection{Stage 1: magma flow along host-rock anisotropy}

The Sondalo gabbro was emplaced during the Permian in the Campo unit. This unit is characterized by a well-developed, pre-intrusion, regional S2 fabric steeply dipping either to the Northeast or Southwest (Fig. 2A). During its intrusion, the magma incorporated numerous xenoliths of the host-rock. The present-day parallelism of the tabular xenoliths with respect to the regional S2 fabric indicates that most of them preserve their original orientations with respect to the host-rock and were not tilted during the intrusion (Fig. 3C). In the core of the pluton, the magmatic foliation is parallel to the xenolith orientation, with a mostly vertical 
magnetic lineation. Therefore, magmatic flow occurred vertically in between the metapelitic screens without significant deformation of the host-rock at this stage (Fig. 14A). Locally, the laminar magma flow may have been perturbed as shown by magmatic fabric wrapping around the xenoliths and at the margins of the pluton.

The presence of pre-D3 leucosomes in the contact aureole indicates that HT metamorphism occurred before D3. In contact with fertile metapelites, mafic magma caused HT-metamorphism grading from upper amphibolite conditions in the contact aureole to granulite facies conditions in the core of the pluton (Petri et al., 2016; Braga et al., 2001). Granitic melt segregated from the migmatites contaminated the mafic magma, as indicated by the trace element composition of zircon, and the LREE enrichment of BZ samples with respect to a parental N-MORB liquid (Tribuzio et al., 1999; Petri et al., 2017). The highest metamorphic conditions are recorded in the core of the pluton, where Grt-Sil-Crd granulites equilibrated at $5.5 \mathrm{kbar} / 930^{\circ} \mathrm{C}$, indicating that the presently exposed xenoliths in the core of the pluton were located at $\sim 20 \mathrm{~km}$ depth during this intrusion stage. Conversely, the presence of post-D3 andalusite in the host-rock indicates that the Campo unit was at about $\sim 15 \mathrm{~km}(P<4.5 \mathrm{kbar})$ during the intrusion (see discussion in Petri et al., 2016). The emplacement of mafic magma occurred at around $289 \pm 4 \mathrm{Ma}$, in agreement with the similar age obtained in two migmatite samples of the contact aureole dated at $289 \pm 4$ Ma and $288 \pm 5 \mathrm{Ma}$ (Petri et al., 2017).

\subsubsection{Stage 2: rise of the core of the pluton and material transfer in the aureole}

The second intrusion stage is indicated by a change in the rheological behavior of the host-rock with respect to the magma. The steeply North-dipping magmatic foliation, which originated during phase 1 , was transposed into a sub-vertical to vertical magmatic foliation that follows the border of the pluton. This process is best documented in both eastern and western margins of the pluton, where the strike of the new magmatic fabric lies at high angle to that of the foliation in the $\mathrm{CZ}$. The new magmatic foliation is concordant with the S3 foliation, which is present in the contact aureole and in few marginal xenoliths. This relation is interpreted as reflecting the deformation of the host-rock during a second phase of pluton emplacement. At this stage, the $\mathrm{CZ}$ of the pluton which preserves the Sm1 fabric became mechanically and spatially isolated from the $\mathrm{S} 2$ bearing host-rock by the newly formed structural aureole rimming the pluton. This structural aureole encompasses the Sm2-bearing BZ of the pluton and the S3bearing contact aureole (see Figs 2 and 14). The pluton was still increasing in size, as indicated by the incorporation of a few folded and deformed xenoliths (Figs 2A and 14AB). Eventually, the solidification of the intrusion was marked by compaction causing a flattening strain in the rim of the pluton, explaining the planar AMS ellipsoids in the BZ.

Notably, the host Campo unit away from the intrusion is unaffected by deformation (Fig. 14AB). Petri et al. (2016) showed that during D3, rocks were exhumed from $\sim 20 \mathrm{~km}$ (5.5 kbar) to the final emplacement depth of $\sim 15 \mathrm{~km}(P<4.5 \mathrm{kbar}$; Fig. 14B). Synchronously, internal xenoliths were exhumed and transported from $\sim 20 \mathrm{~km}(5.5 \mathrm{kbar})$ to the depth of $\sim 15 \mathrm{~km}(4.5$ kbar). Consequently, the syn-emplacement D3 event is associated to pervasive and ductile deformation during exhumation of the host-rock in the contact aureole (Fig. 14B). As xenoliths are parallel and aligned along the host-rock foliation and do not present different $P-T$ evolutions, we suggest that all xenoliths were exhumed during an en-masse magma ascent episode (Fig. 14B). We propose that shearing occurred at the margin of the pluton and produced 
the magmatic foliation in the BZ while the core of the pluton remained poorly affected. An upper age limit for this process is given by the $288 \pm 5 \mathrm{Ma} \mathrm{U}-\mathrm{Pb}$ age of zircon in migmatites showing evidence for supra-solidus D3 deformation (Petri et al., 2016). A lower limit of $285 \pm$ $2 \mathrm{Ma}$ is given by diorite sample GM601 apparently cross-cutting the S3 foliation of the migmatites (Petri et al., 2017). Given the lack of evidence for sub-solidus deformation, we propose that the activity of D3 was restricted to supra-solidus conditions (4.8-6 kbar/725-800 ${ }^{\circ} \mathrm{C}$; Petri et al., 2016).

\subsubsection{Lithological zonation of the pluton}

Most of the magma was injected in the host-rock during the first stage of emplacement. The lithological zonation of the Sondalo gabbroic complex, with Ol-gabbro in the CZ, gabbro in the IZ and diorite in the BZ is similar to that of nested diapirs (Bouchez and Diot, 1990; Paterson and Vernon, 1995) and was acquired during this early stage. Numerical models of Schubert et al. (2013) indicate that magmatic zonation may be due to the stratification of a primary deep seated and differentiated magma chamber, with more differentiated melt at the top (diorite) and denser primitive melts at the bottom of the magmatic complex (similar to the Ivrea mafic complex see e.g. Quick et al., 2003). However, this would imply instantaneous magma emplacement, in conflict with a multiple magma injection scenario that can be deduced from the presence of sheeted dike complexes (Fig 4AB), magma mingling features, the spread in $\mathrm{U}-\mathrm{Pb}$ zircon ages, and the current knowledge on magma emplacement mechanisms (Glazner et al., 2004; Annen, 2011; Leuthold et al., 2012). Therefore, we suggest that the zonation was generated by a progressive mixing of the first mafic melts injected in amphibolite-facies, still fertile metasediments of the Campo unit, while subsequent magma injection were likely in contact with already melt-depleted xenoliths. However, magmatic fabrics are apparently not always parallel to the lithological zonation, potentially because of the numerous processes that may have occurred along these contacts (Žák and Paterson, 2005).

\subsection{Magma ascent mechanisms}

The first stage of magma ascent used the mechanical anisotropy of the host-rock without deforming it. Therefore, the mode of ascent is likely to be controlled by fracture opening along the pre-existing host-rock foliation (Fig. 14A), i.e. by diking. Usually crack orientation during diking is controlled by $\sigma_{1}$ and $\sigma_{3}$ orientations (Lister and Kerr, 1991). However, in case of sufficiently high melt pressure combined with small deviatoric stresses that may occur in the middle-lower crust, cracks could open along the host-rock anisotropy such as bedding or foliation planes (Lucas and St-Onge, 1995; Cosgrove, 1997). Magma flow can therefore occur through dikes opened either by the hydrostatic pressure generated by the magma, by tensional tectonic forces, or by passive invasion of the host-rock generating xenolithic blocks and referred in the literature to as the "stoping" process. However, this stoping process does not account for magma ascent over long distances as it is unable to create enough space for the magma to ascend (Glazner and Bartley, 2006) and is unlikely to occur in the middle crust (Paterson et al., 1991). Conversely, the transtensional strike-slip tectonic regime during the Permian (Arthaud and Matte, 1977) may have promoted fast magma migration (e.g. Handy and Streit, 1999; Casini et al., 2015), but the relative role of magma hydrostatic pressure with respect to tectonic forces is difficult to decipher. If the magma rose along a shear zone (e.g. Rutter et al., 1993; Handy and 
Streit, 1999; Zibra et al., 2012), the shear zone activity must have ceased by the complete solidification of the pluton, as no sub-solidus deformation is observed in both the pluton and the contact aureole.

In the second stage, the development of the migmatitic contact aureole caused by heat advection to the fertile metasediments changed the mode of emplacement. Indeed, above a critical melt fraction ( $c a . \sim 25 \%$ ), the viscosity of metasedimentary rocks drastically decreases (Vanderhaeghe and Teyssier, 2001) and migmatites start to flow. Additionally, a switch in the rheology of the magma from Newtonian- to Bingham- or plug-type of magma flow probably occurred (Fig. 14B), as it is expected for cooling magmas (Weinberg and Podladchikov, 1995; Petford, 2003) due to increasing crystallinity. Consequently, softening of the aureole coupled to the strengthening of the crystallizing inner part of the pluton inverted the rheology. It allowed the magma to rise passively a few kilometers by shearing and probably thinning of the contact aureole while preserving the structure of the core of the pluton, hence producing the narrow deformation gradient that represents the structural aureole. The vertical displacement/exchange of material in the contact aureole described here is commonly referred to as (near-field) material transfer processes (Paterson and Fowler Jr, 1993) typical for magmatic diapirs. However, density inversion between less dense underlying magma and denser overlying host-rock (e.g. van den Eeckhout et al., 1986), required for diapiric rise, is unlikely. In case of ascending felsic magma, a switch from diapirism to diking is expected as it meets colder and stiffer rocks higher in the column (Weinberg, 1996). In contrast, the change in deformation style illustrated here exemplifies that the thermal effect of a hot intrusion facilitates the rheological softening of the host-rock in the aureoles of plutons during late stages of magma ascent (Weinberg and Podladchikov, 1994). Potentially, fractional crystallization and assimilation of crustal-derived melts may control magma buoyancy, facilitating further ascent and entraining more mafic and dense magma upwards (e.g. Cruden et al., 1995).

\section{CONCLUSIONS}

Using field observations coupled to Anisotropy of Magnetic Susceptibility, Anisotropy of Anhysteretic Remanent Magnetization and Crystallographic Preferred Orientation of pyroxene, amphibole and ilmenite, we identified two successive fabrics associated to magma flow in the Sondalo gabbroic complex. They reflect a two-stage magma emplacement history. During the first stage, magma flowed upwards along the sub-vertical foliation of the metasedimentary host-rock by fracture opening without apparent deformation (i.e. by "diking"). Synchronously, heat dissipation to the host-rock developed a migmatitic contact aureole, while granulitic xenoliths were incorporated during magma ascent. The rheological softening associated to an increasing melt fraction in the contact aureole, and the increasing viscosity of crystallizing magma in the pluton triggered a second stage of magma ascent. It was characterized by the en-masse rise of the pluton, during which xenoliths originally equilibrated at $\sim 20 \mathrm{~km}$ were juxtaposed with the host-rock at $\sim 15 \mathrm{~km}$. The exhumation of the core occurred by shearing along the migmatitic contact and the border zone of the pluton that transposed the pre-existing magmatic and metamorphic foliations and formed the structural aureole. Both stages indicate a vertical mafic magma ascent through the crust, and complex interactions with host-rock, so far not reported from felsic intrusions. This study provides new insights on how magma is transferred between deep crustal mafic intrusions and shallow granites and volcanics. 


\section{ACKNOWLEDGMENTS AND DATA}

Fieldwork has been financed through an ExxonMobil research grant accorded to G. Manatschal. G. Morvan is thanked for the BSE imaging, P. Halodová for help about EBSD acquisition as well as A. Longeau and L. Tanguy for the 3axes-IRM and AARM measurements, respectively. We acknowledge careful reviews of M. Chadima and M. I. Spalla and editorial advice by M. Mattei and A. J. Cavosie. The full dataset is available upon request to B. Petri.

\section{REFERENCES CITED}

Andreatta, C., 1952, Polymetamorphose und Tektonik in der Ortlergruppe: Neues Jahrbuch für Mineralogie Monatshefte, p. 13-28.

Annen, C., 2011, Implications of incremental emplacement of magma bodies for magma differentiation, thermal aureole dimensions and plutonism-volcanism relationships: Tectonophysics, v. 500, p. 3-10, doi: http://dx.doi.org/10.1016/j.tecto.2009.04.010.

Annen, C., and Sparks, R.S.J., 2002, Effects of repetitive emplacement of basaltic intrusions on thermal evolution and melt generation in the crust: Earth and Planetary Science Letters, v. 203, p. 937-955, doi: http://dx.doi.org/10.1016/S0012-821X(02)00929-9.

Archanjo, C.J., Bouchez, J.-L., Corsini, M., and Vauchez, A., 1994, The Pombal granite pluton: Magnetic fabric, emplacement and relationships with the Brasiliano strike-slip setting of NE Brazil (Paraiba State): Journal of Structural Geology, v. 16, p. 323-335, doi: http://dx.doi.org/10.1016/0191-8141(94)90038-8.

Arthaud, F., and Matte, P., 1977, Late Paleozoic strike-slip faulting in the southern Europe and northern Africa: Result of a right-lateral shear zone between the Appalachians and the Urals: Geological Society of America Bulletin, v. 88, p. 1305-1320.

Bachmann, G., and Grauert, B., 1981, Radiometrische Alterbestimmungen des Gabbro von Sondalo. Oberes Velltlin, Italienische Alpen: Fortschritte der Mineralogie, v. 59, p. 1113.

Bachmann, F., Hielscher, R., and Schaeben, H., 2010, Texture analysis with MTEX-free and open source software toolbox: Solid State Phenomena, v. 160, p. 63-68.

Baletti, L., Zanoni, D., Spalla, M.I., and Gosso, G., 2012, Structural and petrographic map of the Sassa gabbro complex (Dent Blanche nappe, Austroalpine tectonic system, Western Alps, Italy): Journal of Maps, v. 8, p. 413-430.

Beltrando, M., Rubatto, D., Compagnoni, R., and Lister, G., 2007, Was the Valaisan basin floored by oceanic crust? Evidence of Permian magmatism in the Versoyen unit (Valaisan domain, NW Alps): Ofioliti, v. 32, p. 85-99.

Benn, K., and Allard, B., 1989, Preferred mineral orientations related to magmatic flow in ophiolite layered gabbros: Journal of Petrology, v. 30, p. 925-946.

Bergomi, M.A., and Boriani, A., 2012, Late Neoproterozoic - Early Paleozoic accretion of the Southalpine and Austroalpine basements of Central Alps (Italy): Géologie de la France, v. 1, p. 69.

Bianchi Potenza, B., Carimati, R., Potenza, R., and Testa, B., 1985, Considerazioni cronologiche sul filone trachitico di Sondalo (Lombardia, Valtellina): Atti della Società di Scienze Naturali e del Museo Civico di Storia Naturale di Milano, v. 120, p. 141-144.

Biedermann, A.R., Koch, C.B., Pettke, T., and Hirt, A.M., 2015, Magnetic anisotropy in natural amphibole crystals: American Mineralogist, v. 100, p. 1940-1951, 
http://ammin.geoscienceworld.org/content/100/8-9/1940.abstract.

Biedermann, A.R., Pettke, T., Bender Koch, C., and Hirt, A.M., 2015, Magnetic anisotropy in clinopyroxene and orthopyroxene single crystals: Journal of Geophysical Research: Solid Earth, v. 120, p. 1431-1451.

Borradaile, G.J., and Jackson, J.A., 2010, Structural geology, petrofabrics and magnetic fabrics (AMS, AARM, AIRM): Journal of Structural Geology, v. 32, p. 1519-1551.

Borradaille, G.J., and Henry, B., 1997, Tectonic applications of magnetic susceptibility and its anisotropy: Earth-Science Reviews, v. 42, p. 49-93.

Borsi, S., Ferrara, G., Paganelli, L., and Simboli, G., 1968, Isotopic age measurements of the M. Monzoni intrusive complex: Mineralogica et Petrographica Acta, v. 14, p. 171-183.

Bouchez, J.-L., 2000, Anisotropie de susceptibilité magnétique et fabrique des granites: Comptes Rendus de l'Académie des Sciences - Series IIA - Earth and Planetary Science, v. 330, p. 1-14, doi: http://dx.doi.org/10.1016/S1251-8050(00)00120-8.

Bouchez, J.L., and Diot, H., 1990, Nested granites in question: Contrasted emplacement kinematics of independent magmas in the Zaër pluton, Morocco: Geology , v. 18, p. 966969, http://geology.gsapubs.org/content/18/10/966.abstract.

Braga, R., Callegari, A., Messiga, B., Ottolini, L., Renna, M.R., and Tribuzio, R., 2003, Origin of prismatine from the Sondalo granulites (Central Alps, northern Italy): European Journal of Mineralogy, v. 15, p. 393-400.

Braga, R., Giacomini, F., Messiga, B., and Tribuzio, R., 2001, The Sondalo Gabbroic Complex (Central Alps, Northern Italy): Evidence for Emplacement of Mantle-Derived Melts into Amphibolite Facies Metapelites: Physics and Chemistry of the Earth, Part A: Solid Earth and Geodesy, v. 26, p. 333-342.

Brown, M., 2007, Crustal melting and melt extraction, ascent and emplacement in orogens: mechanisms and consequences: Journal of the Geological Society, v. 164, p. 709-730, doi: 10.1144/0016-76492006-171.

Brown, M., 1994, The generation, segregation, ascent and emplacement of granite magma: the migmatite-to-crustally-derived granite connection in thickened orogens: Earth-Science Reviews, v. 36, p. 83-130.

Bunge, H.-J., 1982, Texture analysis in materials science: mathematical methods: Butterworths, London, $593 \mathrm{p}$.

Burg, J.-P., 1991, Syn-migmatization way-up criteria: Journal of Structural Geology, v. 13, p. 617-623, doi: http://dx.doi.org/10.1016/0191-8141(91)90024-D.

Bussy, F., Venturini, G., Hunziker, J., and Martinotti, G., 1998, U-Pb ages of magmatic rocks of the western Austroalpine Dent-Blanche-Sesia Unit: Schweizerische mineralogische und petrographische Mitteilungen, v. 78, p. 163-168.

Butler, R.F., and Banerjee, S.K., 1975, Theoretical single-domain grain size range in magnetite and titanomagnetite: Journal of Geophysical Research, v. 80, p. 4049-4058, doi: 10.1029/JB080i029p04049.

Campiglio, C., and Potenza, R., 1967, Facies a pirosseno rombico del gabbro di Sondalo (Alta Valtellina): Atti della Società di Scienze Naturali e fel Museo Civico di Storia Naturale di Milano, v. 106, p. 193-208.

Campiglio, C., and Potenza, R., 1964, Facies dioritiche collegate con il gabbro di Sondalo (Alta Valtellina): studio geologico-petrografico: Atti della Società di Scienze Naturali e fel 
Museo Civico di Storia Naturale di Milano, v. 103, p. 325-343.

Campiglio, C., and Potenza, R., 1966, Le facies oliviniche del gabbro di Sondalo (Alta Valtellina, Lombardia): Atti della Società di Scienze Naturali e fel Museo Civico di Storia Naturale di Milano, v. 105, p. 102-122.

Cañón-Tapia, E., and Chávez-Álvarez, M.J., 2004, Theoretical aspects of particle movement in flowing magma: implications for the anisotropy of magnetic susceptibility of dykes: Geological Society, London, Special Publications, v. 238, p. 227-249.

Casini, L., Cuccuru, S., Puccini, A., Oggiano, G., and Rossi, P., 2015, Evolution of the CorsicaSardinia Batholith and late-orogenic shearing of the Variscides: Tectonophysics, v. 646, p. 65-78, doi: http://dx.doi.org/10.1016/j.tecto.2015.01.017.

Clark, D.A., and Tonkin, C., 1994, Magnetic anomalies due to pyrrhotite: examples from the Cobar area, N.S.W., Australia: Journal of Applied Geophysics, v. 32, p. 11-32, doi: http://dx.doi.org/10.1016/0926-9851(94)90006-X.

Clemens, J.D., and Mawer, C.K., 1992, Granitic magma transport by fracture propagation: Tectonophysics, v. 204, p. 339-360, doi: http://dx.doi.org/10.1016/0040-1951(92)90316$\mathrm{X}$.

Coffin, M.F., and Eldholm, O., 1994, Large igneous procinves: crustal structure, dimensions, and external consequences: Reviews of Geophysics, v. 32, p. 1-36.

Collins, W.J., and Sawyer, E.W., 1996, Pervasive granitoid magma transfer through the lowermiddle crust during non-coaxial compressional deformation: Journal of Metamorphic Geology, v. 14, p. 565-579.

Cosgrove, J.W., 1997, The influence of mechanical anisotropy on the behaviour of the lower crust: Tectonophysics, v. 280, p. 1-14, doi: http://dx.doi.org/10.1016/S00401951(97)00145-5.

Cruden, A.R., Koyi, H., and Schmeling, H., 1995, Diapiric basal entrainment of mafic into felsic magma: Earth and Planetary Science Letters, v. 131, p. 321-340, doi: http://dx.doi.org/10.1016/0012-821X(95)00033-9.

Demarchi, G., Quick, J.E., Sinigoi, S., and Mayer, A., 1998, Pressure gradient and original orientation of a lower-crustal intrusion in the Ivrea-Verbano zone, Northern Italy: Journal of Geology, v. 106, p. 609-622.

van den Eeckhout, B., Grocott, J., and Vissers, R., 1986, On the role of diapirism in the segregation, ascent and final emplacement of granitoid magmas-discussion: Tectonophysics, v. 127, p. 161-166, doi: http://dx.doi.org/10.1016/0040-1951(86)900867.

Frandsen, C., Stipp, S.L.S., McEnroe, S.A., Madsen, M.B., and Knudsen, J.M., 2004, Magnetic domain structures and stray fields of individual elongated magnetite grains revealed by magnetic force microscopy (MFM): Physics of the Earth and Planetary Interiors, v. 141, p. 121-129, doi: http://dx.doi.org/10.1016/j.pepi.2003.12.001.

Gazzola, D., Gosso, G., Pulcrano, E., and Spalla, M.I., 2000, Eo-Alpine HP metamorphism in the Permian intrusives from the steep belt of the central Alps (Languard-Campo nappe and Tonale Series): Geodinamica Acta, v. 13, p. 149-167.

Geoffroy, L., Callot, J.P., Aubourg, C., and Moreira, M., 2002, Magnetic and plagioclase linear fabric discrepancy in dykes: a new way to define the flow vector using magnetic foliation: Terra Nova, v. 14, p. 183-190. 
Gerya, T., and Burg, J.P., 2007, Intrusion of ultramafic magmatic bodies into the continental crust: Numerical simulation: Physics of the Earth and Planetary Interiors, v. 160, p. 124142.

Giacomini, F., 1997, Studio meso-microstrutturale e petrologico del basamento cristallino della zona compresa tra la Val di Scala e la Valle delle Presure (Alta Valtellina): University of Pavia, unpublished master thesis, $94 \mathrm{p}$.

Glazner, A.F., and Bartley, J.M., 2006, Is stoping a volumetrically significant pluton emplacement process? Geological Society of America Bulletin, v. 118, p. 1189-1195.

Glazner, A.F., Bartley, J.M., Coleman, D.S., Gray, W., and Taylor, R.Z., 2004, Are plutons assembled over millions of years by amalgamation from small magma chambers? GSA today, v. 14, p. 4-12.

Gosso, G., Salvi, F., Spalla, M.I., and Zucali, M., 2004, Map of deformation partitioning in the polydeformed and polymetamorphic Austroalpine basement of the Central Alps (Upper Valtellina and Val Camonica, Italy), in Pasquarè, G., Venturini, C., and Groppelli, G. eds., Mapping Geology in Italy, APAT, Roma, p. 291-300.

Handy, M.R., and Streit, J.E., 1999, Mechanics and mechanisms of magmatic underplating: inferences from mafic veins in deep crustal mylonite: Earth and Planetary Science Letters, v. 165, p. 271-286, doi: http://dx.doi.org/10.1016/S0012-821X(98)00272-6.

Hansmann, W., Müntener, O., and Hermann, J., 2001, U-Pb zircon geochronology of a tholeiitic intrusion and associated migmatites at a continental crust-mantle transition, Val Malenco, Italy: Schweizerische mineralogische und petrographische Mitteilungen, v. 81, p. 239255.

Hasalová, P., Weinberg, R.F., and Macrae, C., 2011, Microstructural evidence for magma confluence and reusage of magma pathways: implications for magma hybridization, Karakoram Shear Zone in NW India: Journal of Metamorphic Geology, v. 29, p. 875-900.

Higgins, M., 1991, The origin of laminated and massive anorthosite, Sept Iles layered intrusion, Québec, Canada: Contributions to Mineralogy and Petrology, v. 106, p. 340-354, doi: $10.1007 / \mathrm{bf00324562.}$

Hoinkes, G., and Thöni, M., 1993, Evolution of the Ötztal-Stubai, Scarl-Campo and Ulten Basement Units, in Raumer, J.F. and Neubauer, F. eds., Pre-Mesozoic Geology in the Alps, Berlin Heidelberg, Springer Berlin Heidelberg, p. 485-494, doi: 10.1007/978-3-64284640-3_29.

Hrouda, F., 1982, Magnetic anisotropy of rocks and its application in geology and geophysics: Geophysical Surveys, v. 5, p. 37-82.

Hrouda, F., 2002, The use of the anisotropy of magnetic remanence in the resolution of the anisotropy of magnetic susceptibility into its ferromagnetic and paramagnetic components: Tectonophysics, v. 347, p. 269-281, doi: http://dx.doi.org/10.1016/S00401951(02)00075-6.

Hrouda, F., Chlupáčová, M., and Rejl, L., 1971, The mimetic fabric of magnetite in some foliated granodiorites, as indicated by magnetic anisotropy: Earth and Planetary Science Letters, v. 11, p. 381-384, doi: http://dx.doi.org/10.1016/0012-821X(71)90198-1.

Hrouda, F., and Kahan, Š., 1991, The magnetic fabric relationship between sedimentary and basement nappes in the High Tatra Mountains, N. Slovakia: Journal of Structural Geology, v. 13 , p. 431-442. 
Huppert, H.E., and Sparks, R.S.J., 1988, The generation of granitic magmas by intrusion of basalt into continental crust: Journal of Petrology, v. 29, p. 599-624.

Jagoutz, O., Müntener, O., Burg, J.P., Ulmer, P., and Jagoutz, E., 2006, Lower continental crust formation through focused flow in km-scale melt conduits: The zoned ultramafic bodies of the Chilas Complex in the Kohistan island arc (NW Pakistan): Earth and Planetary Science Letters, v. 242, p. 320-342, doi: http://dx.doi.org/10.1016/j.epsl.2005.12.005.

Jelínek, V., 1978, Statistical processing of anisotropy of magnetic susceptibility measured on groups of specimens: Studia Geophysica et Geodaetica, v. 22, p. 50-62, doi: 10.1007/BF01613632.

Koenig, M.A., 1964, Geologisch-petrographische Untersuchungen im oberen Veltlin: PhD thesis, Universität Zurich, $\mathrm{PhD}$ thesis, Universität Zurich, $187 \mathrm{p} \mathrm{p}$.

Kratinová, Z., Ježek, J., Schulmann, K., Hrouda, F., Shail, R.K., and Lexa, O., 2010, Noncoaxial K-feldspar and AMS subfabrics in the Land's End granite, Cornwall: Evidence of magmatic fabric decoupling during late deformation and matrix crystallization: Journal of Geophysical Research: Solid Earth, v. 115, p. n/a-n/a, doi: 10.1029/2009JB006714.

Lagroix, F., and Borradaile, G.J., 2000, Magnetic fabric interpretation complicated by inclusions in mafic silicates: Tectonophysics, v. 325, p. 207-225, doi: http://dx.doi.org/10.1016/S0040-1951(00)00125-6.

Lattard, D., Enelmann, R., Kontny, A., and Sauerzapf, U., 2006, Curie temperatures of synthetic titanomagnetites in the Fe-Ti-O system: Effects of composition, crystal chemistry, and thermomagnetic methods: Journal of Geophysical Research: Solid Earth, v. 111, p. 1-18.

Lehmann, J., Schulmann, K., Edel, J., Ježek, J., Hrouda, F., Lexa, O., and Chopin, F., 2013, Structural and anisotropy of magnetic susceptibility records of granitoid sheets emplacement during growth of a continental gneiss dome (Central Sudetes, European Variscan Belt): Tectonics, v. 32, p. 797-820.

Leuthold, J., Müntener, O., Baumgartner, L.P., Putlitz, B., Ovtcharova, M., and Schaltegger, U., 2012, Time resolved construction of a bimodal laccolith (Torres del Paine, Patagonia): Earth and Planetary Science Letters, v. 325-326, p. 85-92, doi: http://dx.doi.org/10.1016/j.epsl.2012.01.032.

Lister, J.R., and Kerr, R.C., 1991, Fluid-mechanical models of crack propagation and their application to magma transport in dykes: Journal of Geophysical Research: Solid Earth, v. 96, p. 10049-10077.

Lowrie, W., 1990, Identification of ferromagnetic minerals in a rock by coercivity and unblocking temperature properties: Geophysical Research Letters, v. 17, p. 159-162.

Lucas, S.B., and St-Onge, M.R., 1995, Syn-tectonic magmatism and the development of compositional layering, Ungava Orogen (northern Quebec, Canada): Journal of Structural Geology, v. 17, p. 475-491, doi: http://dx.doi.org/10.1016/0191-8141(94)00076-C.

Mahan, K.H., Bartley, J.M., Coleman, D.S., Glazner, A.F., and Carl, B.S., 2003, Sheeted intrusion of the synkinematic McDoogle pluton, Sierra Nevada, California: Geological Society of America Bulletin, v. 115, p. 1570-1582, doi: 10.1130/b22083.1.

Mainprice, D., Bachmann, F., Hielscher, R., and Schaeben, H., 2014, Descriptive tools for the analysis of texture projects with large datasets using MTEX: strength, symmetry and components: Geological Society, London, Special Publications , v. 409, 
http://sp.lyellcollection.org/content/early/2014/08/01/SP409.8.abstract.

Mair, V., and Schuster, R., 2003, New geochronological data from the austroalpine Ortler crystalline in the Martell Valley (Southern Tyrol, Itialy): Mitteilung Österreichische Mineralogische Gesellschaft, v. 148, p. 215-217.

McKenzie, D., 1984, The Generation and Compaction of Partially Molten Rock: Journal of Petrology, v. 25, p. 713-765, doi: 10.1093/petrology/25.3.713.

Meier, A., 2003, The Periadriatic Fault System in Valtellina (N-Italy) and the Evolution of the Southwestern Segment of the Eastern Alps: PhD Thesis, ETH Zurich, PhD Thesis, ETH Zurich, $190 \mathrm{p} \mathrm{p}$.

Meli, S., Montanini, A., Thöni, M., and Frank, W., 1996, Age of mafic granulite blocks from the External Liguride Units (Northern Apennines, Italy): Memorie di scienze geologiche, v. 48, p. $65-72$.

Menand, T., 2011, Physical controls and depth of emplacement of igneous bodies: A review: Tectonophysics, v. 500, p. 11-19, doi: http://dx.doi.org/10.1016/j.tecto.2009.10.016.

Miller, R.B., and Paterson, S.R., 2001, Construction of mid-crustal sheeted plutons: Examples from the North Cascades, Washington: Geological Society of America Bulletin, v. 113, p. 1423-1442, doi: 10.1130/0016-7606(2001)113<1423:comcsp>2.0.co;2.

Miller, C., and Thöni, M., 1997, Eo-alpine eclogitisation of Permian MORB-type gabbros in the Koralpe (Eastern Alps, Austria): new geochronological, geochemical and petrological data: Chemical Geology, v. 137, p. 283-310, doi: http://dx.doi.org/10.1016/S00092541(96)00165-9.

Miller, C., Thöni, M., Goessler, W., and Tessadri, R., 2011, Origin and age of the Eisenkappel gabbro to granite suite (Carinthia, SE Austrian Alps): Lithos, v. 125, p. 434-448, doi: http://dx.doi.org/10.1016/j.lithos.2011.03.003.

Mohn, G., Manatschal, G., Beltrando, M., Masini, E., and Kusznir, N., 2012, Necking of continental crust in magma-poor rifted margins: Evidence from the fossil Alpine Tethys margins: Tectonics, v. 31, p. 1-28.

Mohn, G., Manatschal, G., Masini, E., and Müntener, O., 2011, Rift-related inheritance in orogens: a case study from the Austroalpine nappes in Central Alps (SE-Switzerland and N-Italy): International Journal of Earth Sciences, v. 100, p. 937-961, doi: 10.1007/s00531010-0630-2.

Monjoie, P., Bussy, F., Schaltegger, U., Mulch, A., Lapierre, H., and Pfeifer, H.-R., 2007, Contrasting magma types and timing of intrusion in the Permian layered mafic complex of Mont Collon (Western Alps, Valais, Switzerland): evidence from U/Pb zircon and 40Ar/39Ar amphibole dating: Swiss Journal of Geosciences, v. 100, p. 125-135, doi: 10.1007/s00015-007-1210-8.

Del Moro, A., Martin, S., and Prosser, G., 1999, Migmatites of the Ulten Zone (NE Italy), a Record of Melt Transfer in Deep Crust: Journal of Petrology, v. 40, p. 1803-1826, doi: 10.1093/petroj/40.12.1803.

Del Moro, A., and Notarpietro, A., 1987, Rb-Sr Geochemistry of some Hercynian granitoids overprinted by eo-Alpine metamorphism in the Upper Valtellina, Central Alps: Schweizerische mineralogische und petrographische Mitteilungen, v. 67, p. 295-306.

Del Moro, A., and Visonà, D., 1982, The epiplutonic Hercynian Complex of Bressanone (Brixen, Eastern Alps, Italy): Petrologic and radiometric data: Neues Jahrbuch für 
Mineralogie Abhandlungen, v. 145, p. 66-85.

Mundil, R., Pálfy, J., Renne, P.R., and Brack, P., 2010, The Triassic timescale: new constraints and a review of geochronological data: Geological Society, London, Special Publications, v. 334, p. 41-60, doi: 10.1144/sp334.3.

Müntener, O., and Piccardo, G.B., 2003, Melt migration in ophiolitic peridotites: the message from Alpine-Apennine peridotites and implications for embryonic ocean basins: Geological Society, London, Special Publications, v. 218, p. 69-89, doi: 10.1144/gsl.sp.2003.218.01.05.

Nicolas, A., 1992, Kinematics in Magmatic Rocks with Special Reference to Gabbros: Journal of Petrology, v. 33, p. 891-915, doi: 10.1093/petrology/33.4.891.

Paterson, S.R., and Fowler Jr, T.K., 1993, Re-examining pluton emplacement processes: Journal of Structural Geology, v. 15, p. 191-206, doi: http://dx.doi.org/10.1016/01918141(93)90095-R.

Paterson, S.R., and Miller, R.B., 1998, Mid-crustal magmatic sheets in the Cascades Mountains, Washington: implications for magma ascent: Journal of Structural Geology, v. 20, p. 1345-1363.

Paterson, S.R., and Vernon, R.H., 1995, Bursting the bubble of ballooning plutons: A return to nested diapirds emplaced by multiple processes: Geological Society of America Bulletin, v. 107, p. 1356-1380.

Paterson, S.R., Vernon, R.H., and Fowler, T.K., 1991, Aureole tectonics: Reviews in Mineralogy and Geochemistry, v. 26, p. 673-722, http://rimg.geoscienceworld.org/content/26/1/673.short.

Paterson, S.R., Vernon, R.H., and Tobisch, O.T., 1989, A review of criteria for the identification of magmatic and tectonic foliations in granitoids: Journal of Structural Geology, v. 11, p. 349-363.

Pearce, G.W., and Fueten, F., 1989, An intensive study of magnetic susceptibility anisotropy of amphibolite layers of the Thompson Belt, North Manitoba: Tectonophysics, v. 162, p. 315-329, doi: http://dx.doi.org/10.1016/0040-1951(89)90252-7.

Petford, N., 2003, Rheology of granitic magmas during ascent and emplacement: Annual Review of Earth and Planetary Sciences, v. 31, p. 399-427, doi: 10.1146/annurev.earth.31.100901.141352.

Petford, N., Cruden, A.R., McCaffrey, K.J.W., and Vigneresse, J.-L., 2000, Granite magma formation, transport and emplacement in the Earth's crust: Nature, v. 408, p. 669-673.

Petford, N., Kerr, R.C., and Lister, J.R., 1993, Dike transport of granitoid magmas: Geology, v. 21, p. 845-848.

Petri, B., Mohn, G., Skrzypek, E., Mateeva, Ts., Galster, F., and Manatschal, G., 2017, U-Pb zircon geochronology of the Sondalo gabbroic complex (Central Alps) and its position within the Permian post-Variscan extension: International Journal of Earth Sciences, doi: 10.1007/s00531-017-1465-x.

Petri, B., Mohn, G., Štípská, P., Schulmann, K., and Manatschal, G., 2016, The Sondalo gabbro contact aureole (Campo unit, Eastern Alps): implications for mid-crustal mafic magma emplacement: Contributions to Mineralogy and Petrology, v. 171, p. 52, doi: 10.1007/s00410-016-1263-7.

Pin, C., 1986, Datation U-Pb sur zircons à 285 M.a. du complexe gabbro-dioritique du Val 
Sesia-Val Mastallone et âge tardi-hercynien du métamorphisme granulitique de la zone Ivrea-Verbano (Italie): Comptes Rendus de l'Académie des Sciences. Série 2. Sciences de la Terre et des planètes, v. 9, p. 827-830.

Pohl, F., Froitzheim, N., Geisler-Wierwille, T., and Schlöder, O., 2014, Permian magmatism, Permian detachment faulting, and Alpine thrusting in the Orobic Anticline, southern Alps, Italy: Geophysical Research Abstracts, v. 16, p. EGU2014-6542.

Quick, J.E., Sinigoi, S., and Mayer, A., 1994, Emplacement dynamics of a large mafic intrusion in the lower crust, Ivrea-Verbano Zone, northern Italy: Journal of Geophysical Research, v. 99, p. 21559-21573.

Quick, J.E., Sinigoi, S., Negrini, L., Demarchi, G., and Mayer, A., 1992, Synmagmatic deformation in the underplated igneous complex of the Ivrea-Verbano zone: Geology, v. 20, p. 613-616, doi: 10.1130/0091-7613(1992)020<0613:sditui> 2.3.co;2.

Quick, J.E., Sinigoi, S., Snoke, A.W., Kalakay, T.J., Mayer, A., and Peressini, G., 2003, Geologic map of the southern Ivrea-Verbano Zone, northwestern Italy: U.S. Geological Survey Geologic Investigations Series Map I-2776, scale 1:25,000: , p. 22 p.

Ramberg, H., 1981, Gravity, deformation and the earth's crust, in theory, experiments and geological application: London, Academic Press, 452 p.

Rebay, G., and Spalla, M.I., 2001, Emplacement at granulite facies conditions of the SesiaLanzo metagabbros: an early record of Permian rifting? Lithos, v. 58, p. 85-104, doi: http://dx.doi.org/10.1016/S0024-4937(01)00046-9.

Redler, C., Johnson, T.E., White, R.W., and Kunz, B.E., 2012, Phase equilibrium constraints on a deep crustal metamorphic field gradient: metapelitic rocks from the Ivrea Zone (NW Italy): Journal of Metamorphic Geology, v. 30, p. 235-254, doi: 10.1111/j.15251314.2011.00965.x.

Renne, P.R., Scott, G.R., Glen, J.M.G., and Feinberg, J.M., 2002, Oriented inclusions of magnetite in clinopyroxene: Source of stable remanent magnetization in gabbros of the Messum Complex, Namibia: Geochemistry Geophysics Geosystems, v. 3, p. 1-11.

Richter, C., Kelso, P., and MacLoed, C.J., 1996, Magnetic fabrics and sources of magnetic susceptibility in lower crustal and upper mantle rocks from Hess Deep, in Mével, C., Gillis, K.M., and Allan, J.F. eds., Proceedings of the Ocean Drilling Program, Scientific Results, 147, Ocean Drilling Program, College Station, Texas, p. 393-403, doi: 10.1007/978-3642-84640-3_7.

Rochette, P., 1987, Metamorphic control of the magnetic mineralogy of black shales in the Swiss Alps: toward the use of "magnetic isogrades": Earth and Planetary Science Letters, v. 84, p. 446-456, doi: http://dx.doi.org/10.1016/0012-821X(87)90009-4.

Rochette, P., Aubourg, C., and Perrin, M., 1999, Is this magnetic fabric normal? A review and case studies in volcanic formations: Tectonophysics, v. 307, p. 219-234.

Rochette, P., Jackson, M., and Aubourg, C., 1992, Rock magnetism and the interpretation of anisotropy of magnetic susceptibility: Reviews of Geophysics, v. 30, p. 209-226.

Rudnick, R.L., and Fountain, D.M., 1995, Nature and composition of the continental crust: a lower crustal perspective: Reviews of Geophysics, v. 33, p. 267-309.

Rutter, E., Brodie, K., and Evans, P.J., 1993, Structural geometry, lower crustal magmatic underplating and lithospheric stretching in the Ivrea-Verbano zone, northern Italy: Journal of Structural Geology, v. 15, p. 647-662. 
Sawyer, E.W., Cesare, B., and Brown, M., 2011, When the Continental Crust Melts: Elements, v. 7, p. 229-234, doi: 10.2113/gselements.7.4.229.

Schmid, S., Fügenschuh, B., Kissling, E., and Schuster, R., 2004, Tectonic map and overall architecture of the Alpine orogen: Eclogae Geologicae Helvetiae, v. 97, p. 93-117, doi: 10.1007/s00015-004-1113-x.

Schmid, S.M., and Haas, R., 1989, Transition from near-surface thrusting to Intrabasement Decollement, Schlinig Thrust, eastern Alps: Tectonics, v. 8, p. 697-718, doi: 10.1029/TC008i004p00697.

Schubert, M., Driesner, T., Gerya, T. V, and Ulmer, P., 2013, Mafic injection as a trigger for felsic magmatism: A numerical study: Geochemistry, Geophysics, Geosystems, v. 14, p. 1910-1928.

Schulmann, K., and Ježek, J., 2012, Some remarks on fabric overprints and constrictional AMS fabrics in igneous rocks: International Journal of Earth Sciences, v. 101, p. 705-714.

Schuster, R., and Stüwe, K., 2008, Permian metamorphic event in the Alps: Geology, v. 36, p. 603-606.

Scott, D.R., and Stevenson, D.J., 1986, Magma ascent by porous flow: Journal of Geophysical Research: Solid Earth, v. 91, p. 9283-9296, doi: 10.1029/JB091iB09p09283.

Siivola, J., and Schmid, R., 2007, List of Mineral abbreviations - Recommendations by the IUGS Subcomission on the Systematics of Metamorphic Rocks: IUGS: web version 01.02.07, p. 1-14.

Sinigoi, S., Quick, J.E., Demarchi, G., and Klötzli, U.S., 2016, Production of hybrid granitic magma at the advancing front of basaltic underplating: Inferences from the Sesia Magmatic System (south-western Alps, Italy): Lithos, v. 252-253, p. 109-122, doi: http://dx.doi.org/10.1016/j.lithos.2016.02.018.

Skemer, P., Katayama, I., Jiang, Z., and Karato, S., 2005, The misorientation index: Development of a new method for calculating the strength of lattice-preferred orientation: Tectonophysics, v. 411, p. 157-167, doi: http://dx.doi.org/10.1016/j.tecto.2005.08.023.

Solano, J.M.S., Jackson, M.D., Sparks, R.S.J., and Blundy, J., 2014, Evolution of major and trace element composition during melt migration through crystalline mush: Implications for chemical differentiation in the crust: American Journal of Science, v. 314, p. 895-939, doi: 10.2475/05.2014.01.

Spalla, M.I., Zanoni, D., Marotta, A.M., Rebay, G., Roda, M., Zucali, M., and Gosso, G., 2014, The transition from Variscan collision to continental break-up in the Alps: insights from the comparison between natural data and numerical model predictions: Geological Society, London, Special Publications, v. 405, doi: 10.1144/sp405.11.

Spalla, M.I., Zucali, M., Di Paola, S., and Gosso, G., 2005, A critical assessment of the tectonothermal memory of rocks and definition of tectono-metamorphic units: evidence from fabric and degree of metamorphic transformations: Geological Society, London, Special Publications, v. 243, p. 227-247, doi: 10.1144/gsl.sp.2005.243.01.16.

Staub, R., 1946, Geologische Karte der Berninagruppe und ihrer Umgebung im Oberengadin, Bergell, Val Malenco, Puschlav und Livigno, scale 1:50,000: Speziale Karte 118, Schweizerische Geologische Kommission,.

Thöni, M., 1981, Degree and evolution of the alpine metamorphism in the Austroalpine unit W of the Hohe Tauern in the light of $\mathrm{K} / \mathrm{Ar}$ and $\mathrm{Rb} / \mathrm{Sr}$ age determination on micas: Jahrbuch 
der Geologischen Bundesanstalt, v. 124, p. 111-174.

Thöni, M., and Jagoutz, E., 1992, Some new aspects of dating eclogites in orogenic belts: Sm$\mathrm{Nd}, \mathrm{Rb}-\mathrm{Sr}$, and $\mathrm{Pb}-\mathrm{Pb}$ isotopic results from the Austroalpine Saualpe and Koralpe typelocality (Carinthia/Styria, southeastern Austria): Geochimica et Cosmochimica Acta, v. 56, p. 347-368, doi: http://dx.doi.org/10.1016/0016-7037(92)90138-9.

Thöni, M., Mottana, A., Delitata, M.C., De Capitani, L., and Liborio, G., 1992, The Val Biandino composite pluton: A late Hercynian intrusion into the South-Alpine metamorphic basement of the Alps (Italy): Neues Jahrbuch für Mineralogie Monatshefte, v. 12 , p. $545-554$.

Tobisch, O.T., McNulty, B.A., and Vernon, R.H., 1997, Microgranitoid enclave swarms in granitic plutons, central Sierra Nevada, California: Lithos, v. 40, p. 321-339, doi: http://dx.doi.org/10.1016/S0024-4937(97)00004-2.

Tribuzio, R., Thirlwall, M.F., and Messiga, B., 1999, Petrology, mineral and isotope geochemistry of the Sondalo gabbroic complex (Central Alps, Northern Italy): implications for the origin of post-Variscan magmatism: Contributions to Mineralogy and Petrology, v. 136, p. 48-62, doi: 10.1007/s004100050523.

Ulrich, S., and Mainprice, D., 2005, Does cation ordering in omphacite influence development of lattice-preferred orientation? Journal of Structural Geology, v. 27, p. 419-431, doi: http://dx.doi.org/10.1016/j.jsg.2004.11.003.

Vanderhaeghe, O., and Teyssier, C., 2001, Crustal-scale rheological transitions during lateorogenic collapse: Tectonophysics, v. 335, p. 211-228, doi: http://dx.doi.org/10.1016/S0040-1951(01)00053-1.

Vernon, R.H., 2000, Review of microstructural evidence of magmatic and solid-state flow: Electronic Geosciences, v. 5, p. 1-23.

Vigneresse, J.L., and Clemens, J.D., 2000, Granitic magma ascent and emplacement: neither diapirism nor neutral buoyancy: Geological Society, London, Special Publications , v. 174, p. 1-19, doi: 10.1144/GSL.SP.1999.174.01.01.

Viola, G., Mancktelow, N.S., Seward, D., Meier, A., and Martin, S., 2003, The Pejo fault system: An example of multiple tectonic activity in the Italian Eastern Alps: Geological Society of America Bulletin , v. 115, p. 515-532, http://gsabulletin.gsapubs.org/content/115/5/515.abstract.

Voshage, H., Hofmann, A.W., Mazzucchelli, M., Rivalenti, G., Sinigoi, S., Raczek, I., and Demarchi, G., 1990, Isotopic evidence from the Ivrea Zone for a hybrid lower crust formed by magmatic underplating: Nature, v. 347, p. 731-736, http://dx.doi.org/10.1038/347731a0.

Weinberg, R.F., 1996, Ascent mechanism of felsic magmas: news and views: Earth and Environmental Science Transactions of the Royal Society of Edinburgh, v. 87, p. 95-103, doi: doi:10.1017/S0263593300006519.

Weinberg, R.F., 1999, Mesoscale pervasive felsic magma migration: alternatives to dyking: Lithos, v. 46, p. 393-410.

Weinberg, R.F., and Podladchikov, Y.Y., 1994, Diapiric ascent of magmas through power law crust and mantle: Journal of Geophysical Research: Solid Earth, v. 99, p. 9543-9559.

Weinberg, R.F., and Podladchikov, Y.Y., 1995, The rise of solid-state diapirs: Journal of Structural Geology, v. 17, p. 1189-1195. 
Wiebe, R.A., Jellinek, M., Markley, M.J., Hawkins, D.P., and Snyder, D., 2006, Steep schlieren and associated enclaves in the Vinalhaven granite, Maine: possible indicators for granite rheology: Contributions to Mineralogy and Petrology, v. 153, p. 121, doi: 10.1007/s00410006-0142-z.

Woodcock, N.H., 1977, Specification of fabric shapes using an eigenvalue method: Geological Society of America Bulletin, v. 88, p. 1231, doi: 10.1130/00167606(1977)88<1231:SOFSUA>2.0.CO;2.

Yaouancq, G., and MacLeod, C.J., 2000, Petrofabric investigation of gabbros from the Oman ophiolite: comparison between AMS and rock fabric: Marine Geophysical Researches, v. 21, p. 289-305.

Žák, J., and Paterson, S.R., 2005, Characteristics of internal contacts in the Tuolumne Batholith, central Sierra Nevada, California (USA): Implications for episodic emplacement and physical processes in a continental arc magma chamber: Geological Society of America Bulletin , v. 117, p. 1242-1255, http://gsabulletin.gsapubs.org/content/117/910/1242.abstract.

Zanetti, A., Mazzucchelli, M., Sinigoi, S., Giovanardi, T., Peressini, G., and Fanning, M., 2013, SHRIMP U-Pb Zircon Triassic Intrusion Age of the Finero Mafic Complex (IvreaVerbano Zone, Western Alps) and its Geodynamic Implications: Journal of Petrology, v. 54, p. 2235-2265, doi: 10.1093/petrology/egt046.

Zibra, I., Kruhl, J.H., Montanini, A., and Tribuzio, R., 2012, Shearing of magma along a highgrade shear zone: Evolution of microstructures during the transition from magmatic to solid-state flow: Journal of Structural Geology, v. 37, p. 150-160, doi: http://dx.doi.org/10.1016/j.jsg.2012.01.011. 


\section{FIGURES}

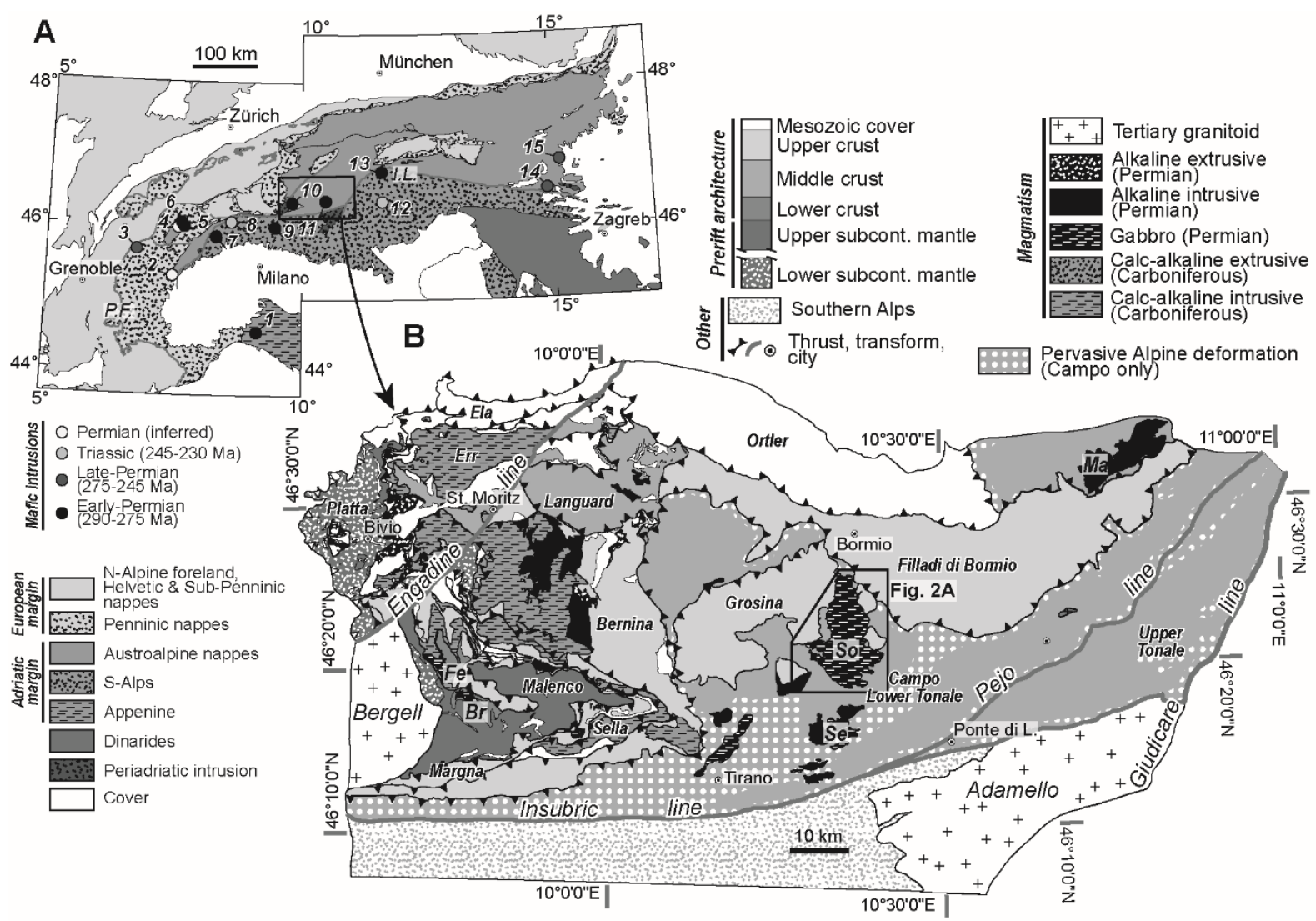

Fig. 1: (A) Tectonic map of the Alps, modified after Schmid et al. (2004) and location of Permian and Triassic mafic intrusives after Spalla et al. (2014): 1-Monte Ragola (Meli et al., 1996); 2-Corio/Monastero (Rebay and Spalla, 2001); 3-Versoyen unit (Beltrando et al., 2007); 4-Sassa (Baletti et al., 2012); 5-Sermenza (Bussy et al., 1998); 6-Mont Collon (Monjoie et al., 2007); 7-Ivrea main gabbro (e.g. Pin, 1986); 8- Finero (Zanetti et al., 2013); 9-Val Biandino (Pohl et al., 2014; Thöni et al., 1992); 10-Fedoz/Braccia (Hansmann et al., 2001); 11-Sondalo (Tribuzio et al., 1999); 12-Monzoni-Predazzo (Borsi et al., 1968; see references in Mundil et al., 2010); 13-Bressanone/Brixen (Del Moro and Visonà, 1982); 14-Eisenkappel (Miller et al., 2011); 15-Bärofen/Gressenberg (Thöni and Jagoutz, 1992; Miller and Thöni, 1997). I.L.: the Insubric Line, P.F.: Penninic Front. (B) Litho-tectonic map of the Austroalpine domain in SE Switzerland and N Italy representing the different pre-rift crustal domains. The map is a compilation of Del Moro and Notarpietro (1987), Del Moro et al. (1999), Gosso et al. (2004), Mohn et al. (2011), Staub (1946), the 1:25,000 geological maps of Switzerland, the 1:10,000 and 1:25,000 geological maps of Italy and personal observations. Zones of pervasive alpine deformation are compiled from Andreatta (1952), Thöni (1981), Meier (2003), Spalla et al. (2005) and personal observations. Black rectangle in (B) reports location of the map in following figures. Main Permian intrusives are reported and correspond to Fe, Fedoz gabbro; Br; Braccia gabbro; So, Sondalo gabbro; Se, Serottini intrusives; and Ma, Martell granite. 


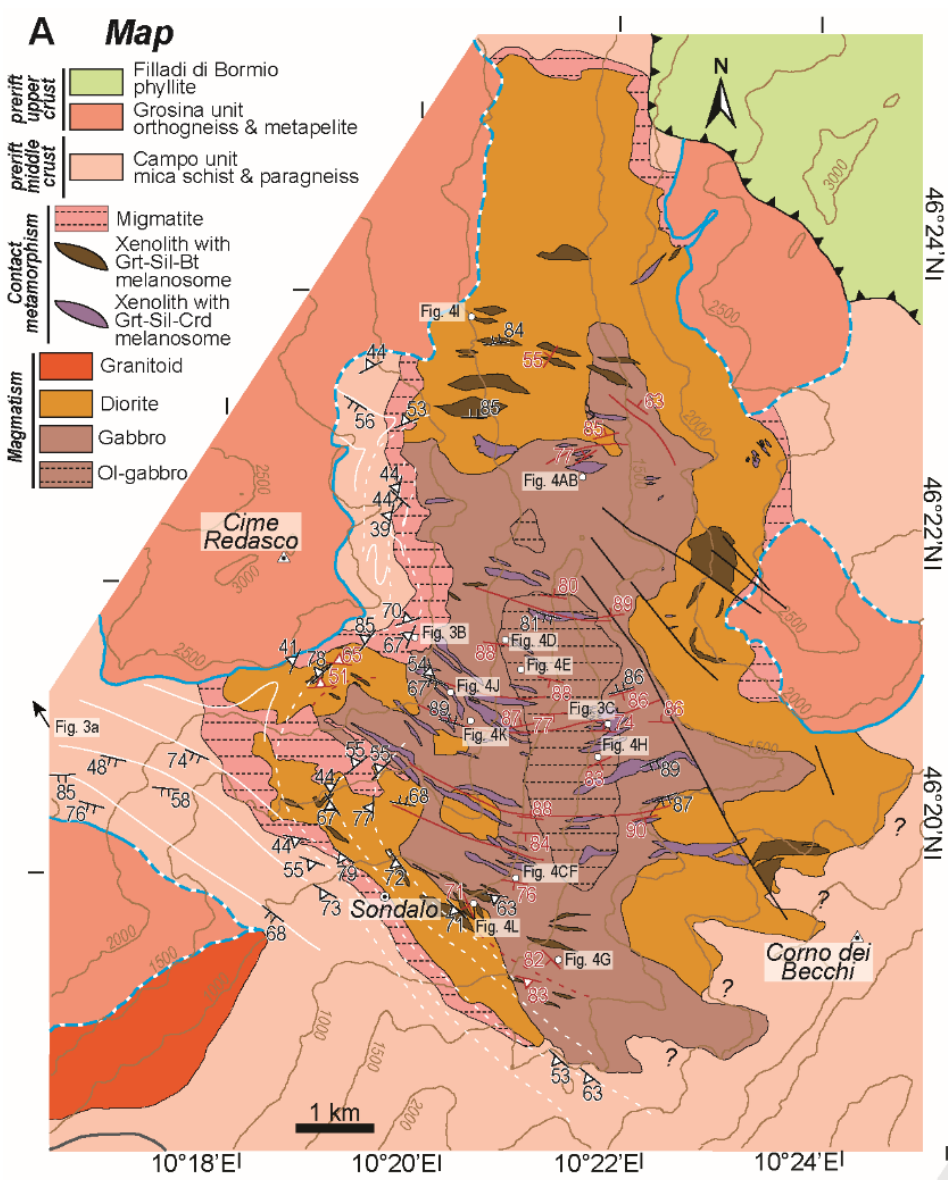

B Planar structures
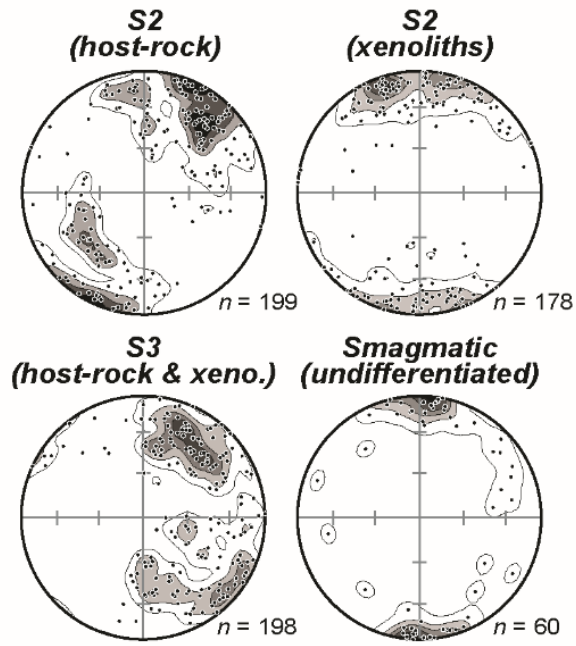

C AMS, AARM \& EBSD sites

$11^{89} \mathrm{~S} 2$, interpretative S2 trace $\triangle 99.0^{\circ} \mathrm{S} 3$, interpretative S3 trace $188^{\circ}$ Sm1, interpretative $\mathrm{Sm} 1$ trace $\triangle^{51}: \mathrm{Sm} 2$, interpretative Sm2 trace

y Alpine thrust

i) Jurassic shear zone

(inferred/observed)

Fault

Location of samples used for pictures and petrology

$\oplus \triangle$ Town, summit
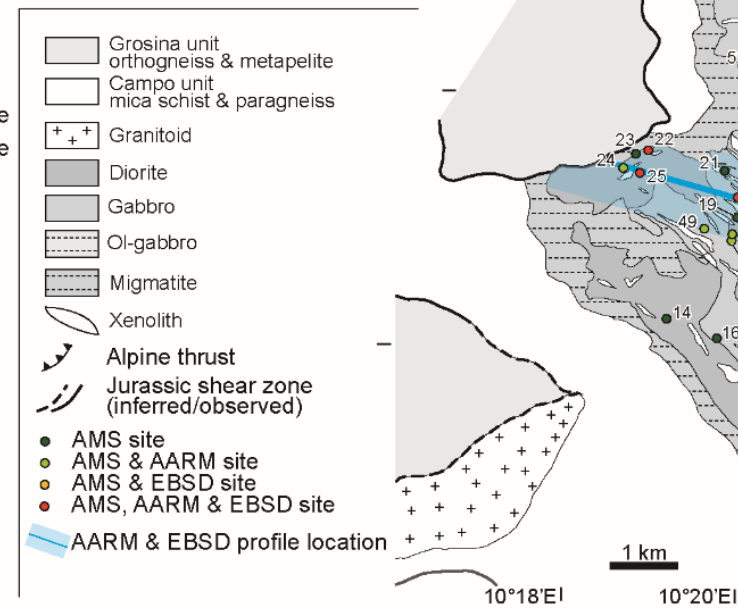

$10^{\circ} 24^{\prime} \mathrm{EI}$

Fig. 2: (A) Geological and structural map of the Sondalo gabbro and the host-rock Campo unit. Location of field and microphotographs (Figs 3 and 4) is indicated. Contour lines are plotted each $500 \mathrm{~m}$. (B) Stereonet plot (equal area, lower hemisphere projection) of S2 and S3 foliations poles (metasediments) and magmatic foliation. (C) Location of stations used for the AMS and EBSD study. 

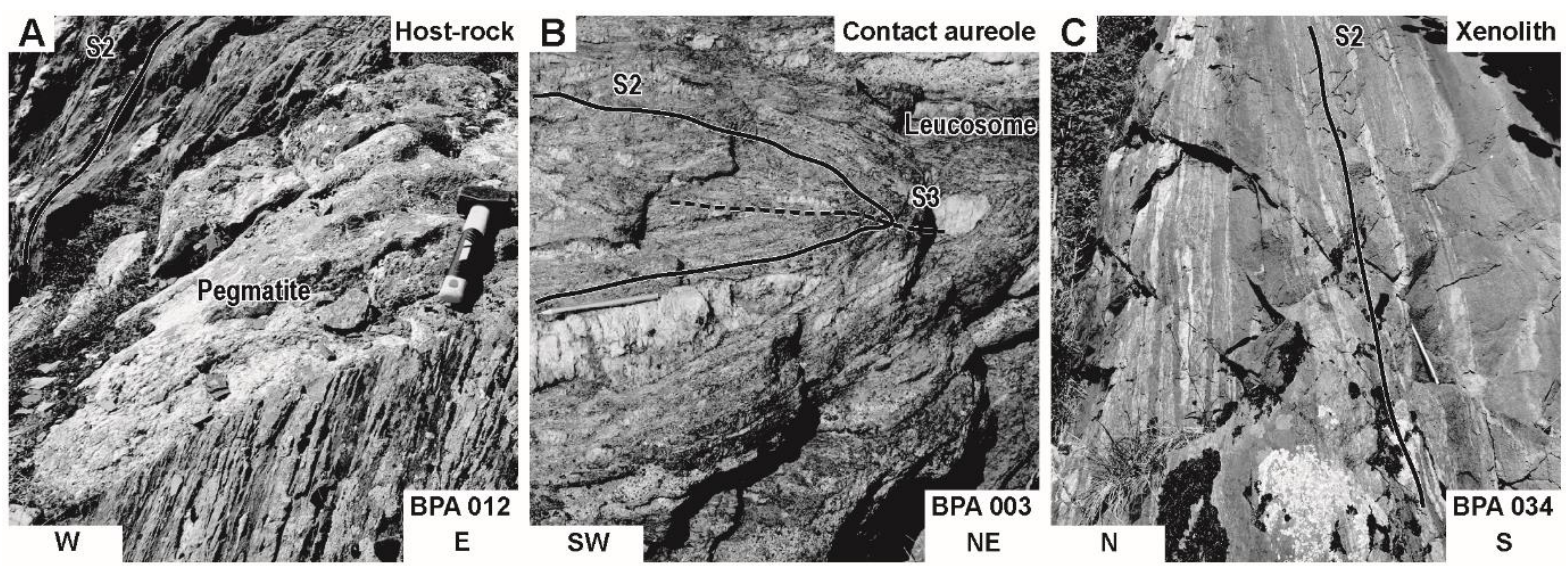

Fig. 3: Field photographs of metasediments. (A) Steeply dipping foliation of host-rock mica schists $4 \mathrm{~km}$ far from the Sondalo gabbro (direction indicated on Fig. 2A). (B) Moderately inclined F3 fold located in the migmatitic contact aureole of the pluton. (C) Granulite-facies metasedimentary xenolith in the core of the pluton preserving the S2 fabric. Location of photographs is indicated on Fig. 2. Hammer and pencils are $26 \mathrm{~cm}$ and $15 \mathrm{~cm}$ in length, respectively. 

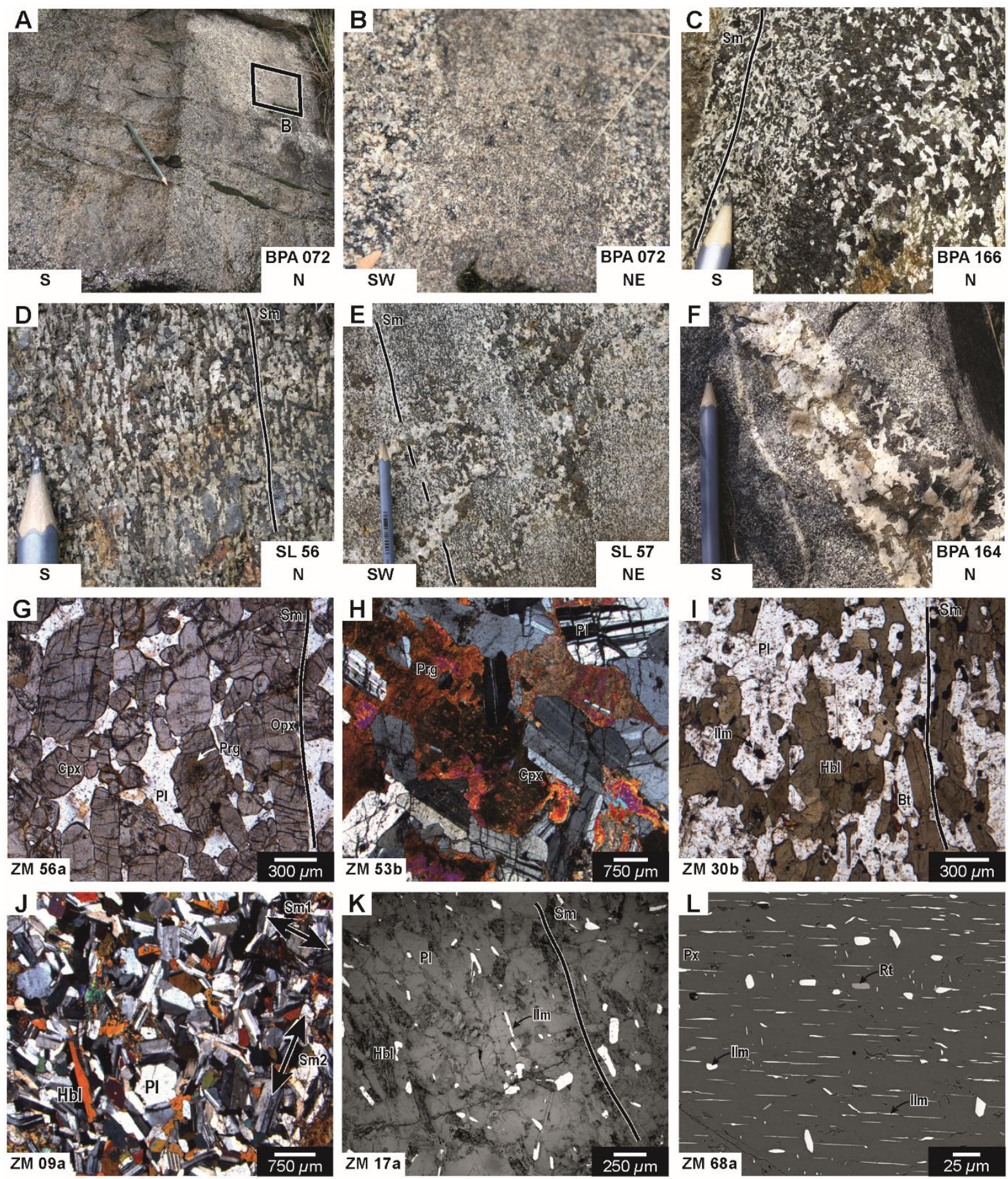

Fig. 4: Field photographs and photomicrographs of magmatic rocks $(\mathrm{G}-\mathrm{J}$ : transmitted light; $\mathrm{K}$ : reflected light; L: back-scattered electron (BSE) image). Sheeted dikes with (A) sub-vertical rhythmic grain-size layering in the center of the pluton and (B) close-up view of the structure, location indicated in (A). (C) In-situ sub-vertical layering and foliation produced by compaction and felsic liquid extraction. (D) Strong foliation defined by shape-preferred orientation of plagioclase and amphibole. (E) Patchy coarse-grained pockets due to late-stage accumulation of interstitial liquid. Note the modal lamination of the fine-grained and foliated gabbro. (F) Weakly foliated gabbro crosscut by a coarse-grained dike with a sharp contact. (G) Oriented Opx-Cpx grains in a mafic cumulate, surrounded by a poikilitic plagioclase monograin. $(\mathrm{H})$ Coarse-grained gabbro with weakly oriented plagioclase and poikilitic Cpx. (I) Diorite with a 
strong shape-preferred orientation of subhedral plagioclase and hornblende. (J) Diorite showing superposition of two magmatic fabrics. (K) Ilmenite along oriented plagioclase crystals. (L) Lamellar exsolution of ilmenite along the cleavages of the pyroxene. Mineral abbreviations follow IUGS recommendations (Siivola and Schmid, 2007). Location of photographs and samples is indicated on Fig. 2. Pencils are $15 \mathrm{~cm}$ in length and $0.7 \mathrm{~cm}$ in thickness.

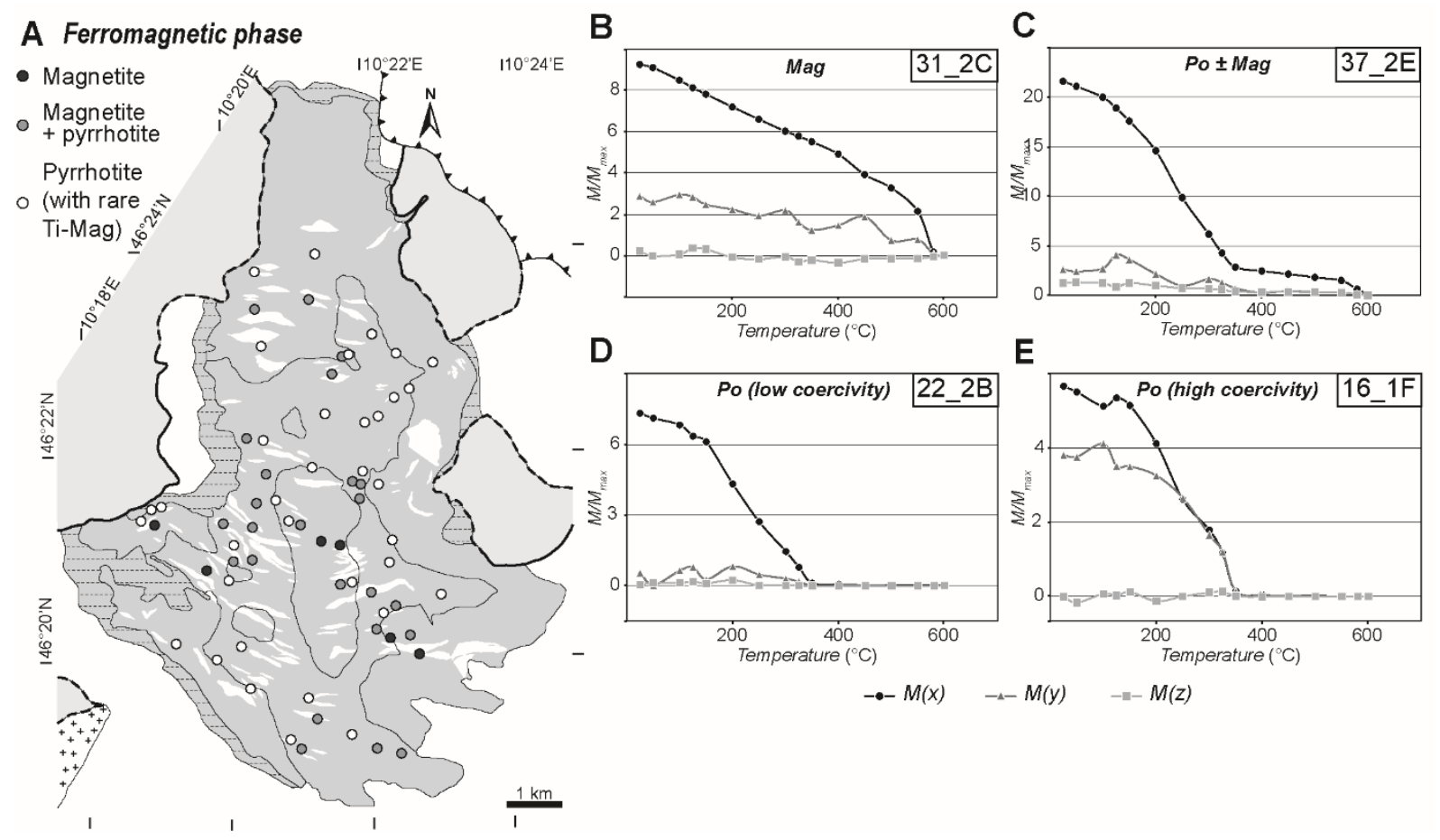

Fig. 5: (A) Synthesis of magnetic mineralogy determination with 3axes-IRM and (B-E) representative experiments representing $\mathrm{M}$ normalized by Mmax in function of temperature for low coercivity $(M(x)$, blue circles), medium coercivity $(M(y)$, red suqares) and high coercivity axes $(M(z)$, green triangles). (B) Magnetite-, (C) pyrrhotite- and magnetite-, (D) low coercivity pyrrhotite- and more rarely $(\mathrm{E})$ high coercivity pyrrhotite-bearing samples. 

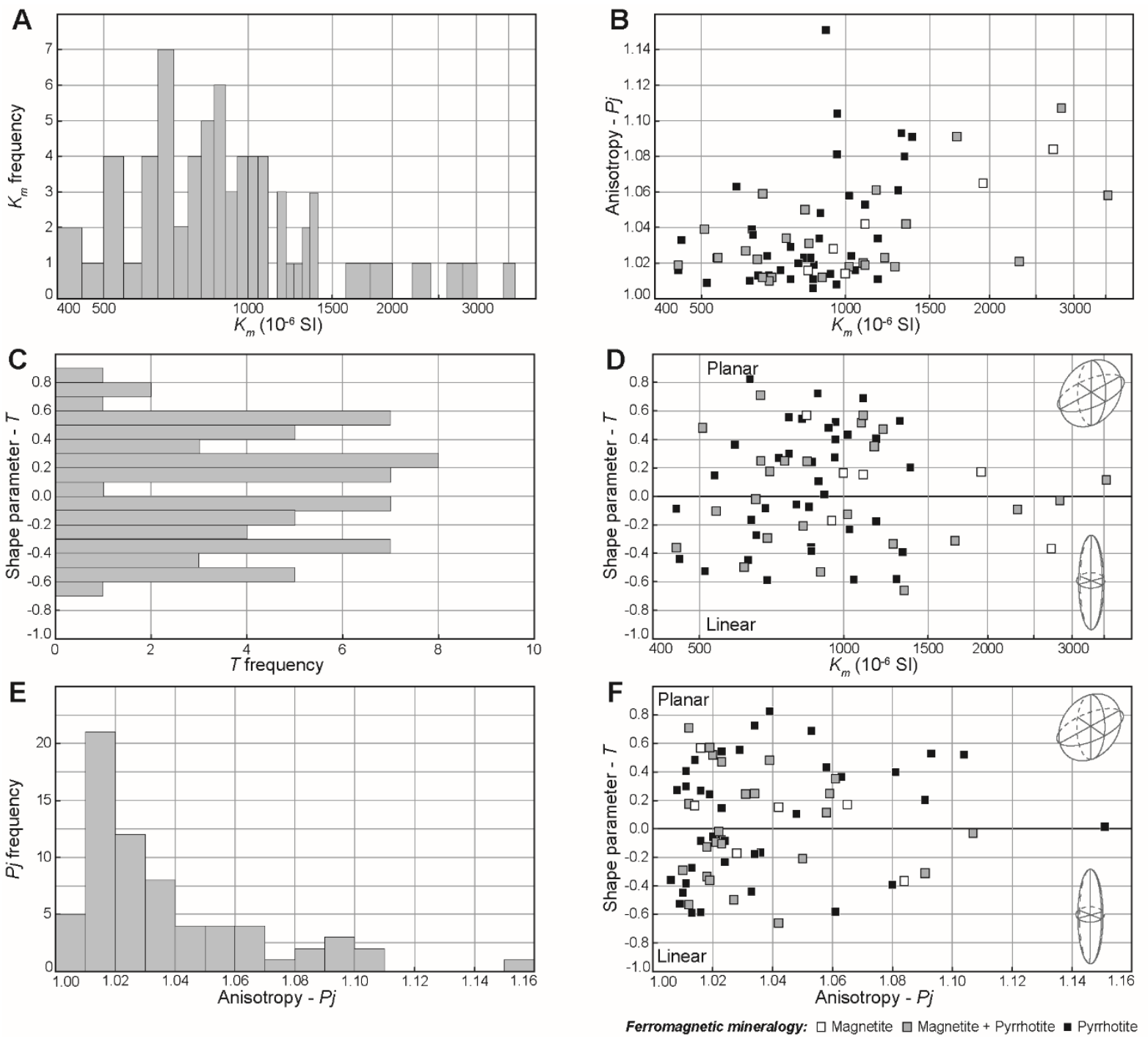

Fig. 6: (A) $K_{m}$ frequency plot; (B) $P j-K_{m}$ diagram; (C) T frequency plot; (D) T- $K_{m}$ diagram; (E) $P j$ frequency plot; (F) T $-P j$ diagram. Plotted values and histograms represent average value per site. Magnetic parameters are calculated using the method of Jelinek (1978). Ferromagnetic mineralogy is deduced from 3axes-IRM measurements (see Fig. 5). 


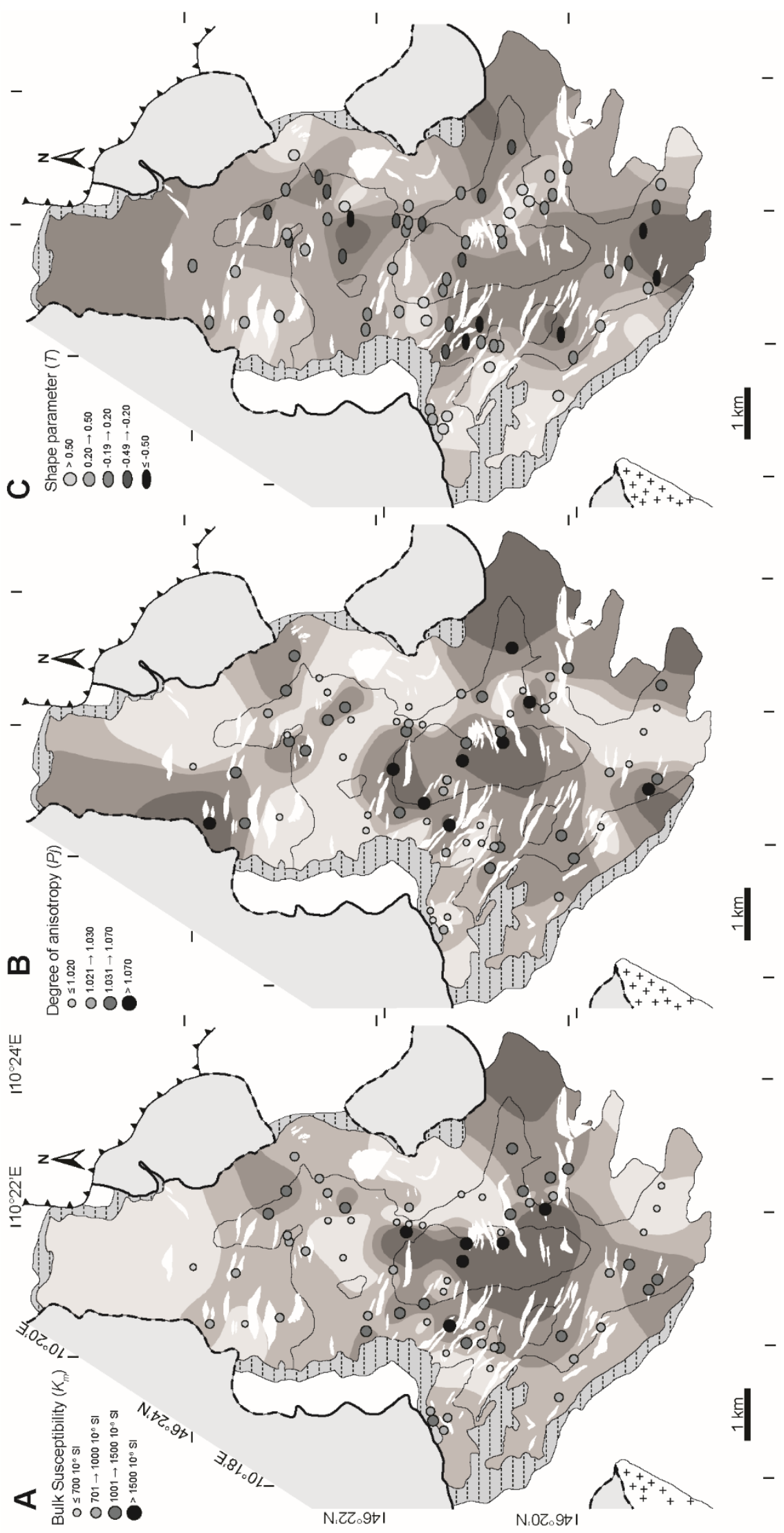

Fig. 7: Maps with (A) bulk susceptibility $K_{m},(\mathrm{~B})$ degree of anisotropy $P j$ and (C) and the shape parameters $\mathrm{T}$ averaged value. Colored background map is obtained through spline interpolation method. Magnetic parameters are calculated using the method of Jelinek (1978). 

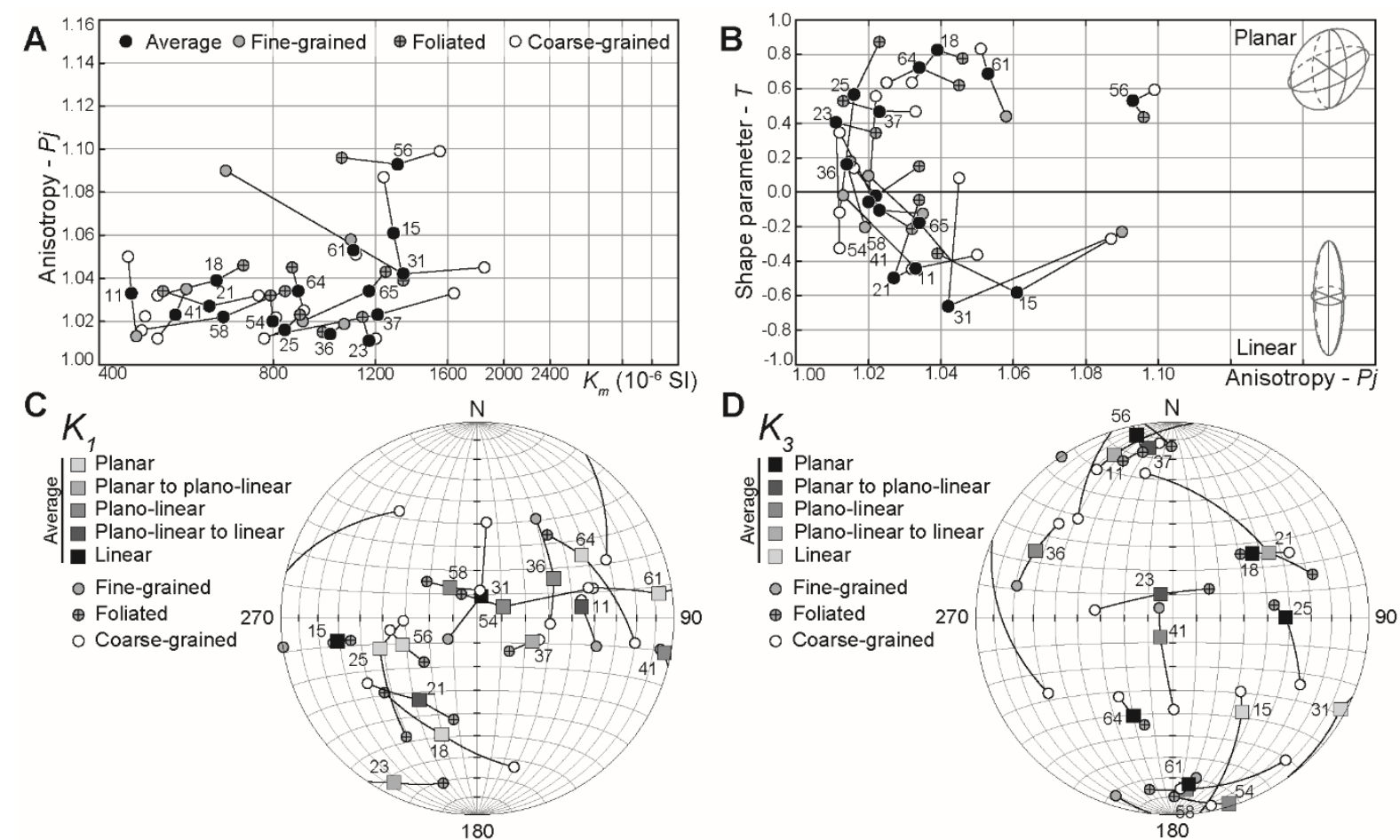

Fig. 8: Averages AMS parameters / textures relationship for cores and outcrops with different magmatic textures (fine-grained, foliated and coarse-grained): (A) $P_{j}-K m$ and (B) $\mathrm{T}-P j$ diagrams; orientation data for (C) the long axis $K_{l}$ and (D) the short axis $K_{3}$ (equal area, lower hemisphere projection). Segments link site average values to average values for cores with similar magmatic textures. Color code indicates site average shape categories defined by the shape parameter $(T)$ from red (not reliable orientation, linear for $K_{3}$ orientation and planar for $K_{1}$ orientation) to green (reliable orientation, planar for $K_{3}$ orientation and linear for $K_{1}$ orientation). Shape parameters categories are defined as follows: planar $(1.0 \geq T>0.5)$; planar to plano-linear $(0.5 \geq T>0.2)$; plano-linear $(0.2 \geq T>-0.2)$; plano-linear to linear $-0.2 \geq T>$ $0.5)$; linear $(-0.5 \geq T \geq-1.0)$. Magnetic parameters are calculated using the method of Jelinek (1978). Location of sites on Fig. 2C. 


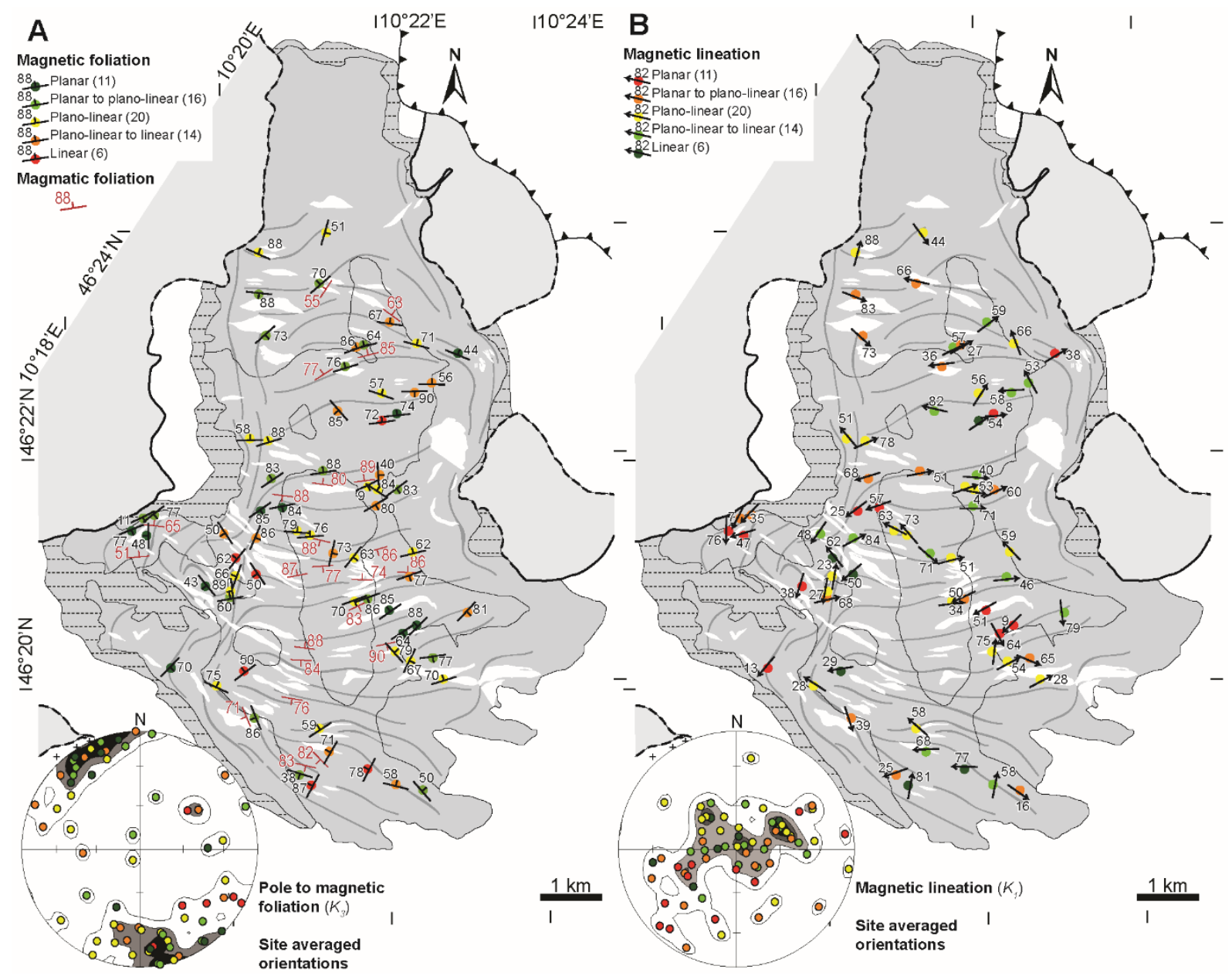

Fig. 9: Maps of (A) magnetic and magmatic foliations and (B) magnetic lineations. Color code indicates shape categories defined by the shape parameter $(T)$ from red (not reliable orientation, linear for $K_{3}$ orientation and planar for $K_{l}$ orientation) to green (reliable orientation, planar for $K_{3}$ orientation and linear for $K_{l}$ orientation). Shape parameters categories are defined as follows: planar $(1.0 \geq \mathrm{T}>0.5)$; planar to plano-linear $(0.5 \geq \mathrm{T}>0.2)$; plano-linear $(0.2 \geq \mathrm{T}>-0.2)$; plano-linear to linear $-0.2 \geq \mathrm{T}>-0.5)$; linear $(-0.5 \geq \mathrm{T} \geq-1.0)$. Magnetic parameters are calculated using the method of Jelinek (1978). Stereonet plot of poles to magnetic foliation $\left(K_{3}\right)$ and magnetic lineations $\left(K_{l}\right)$ are plotted with equal area on lower hemisphere projection.

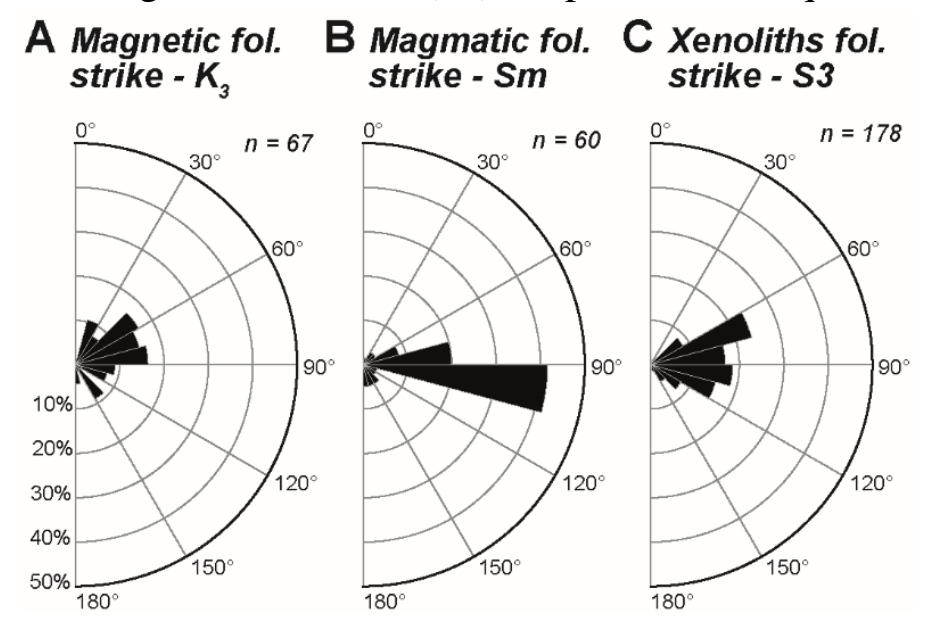

Fig. 10: Half-rose diagrams for (A) magnetic foliation, (B) magmatic foliation and (C) xenolith metamorphic foliation strike. 

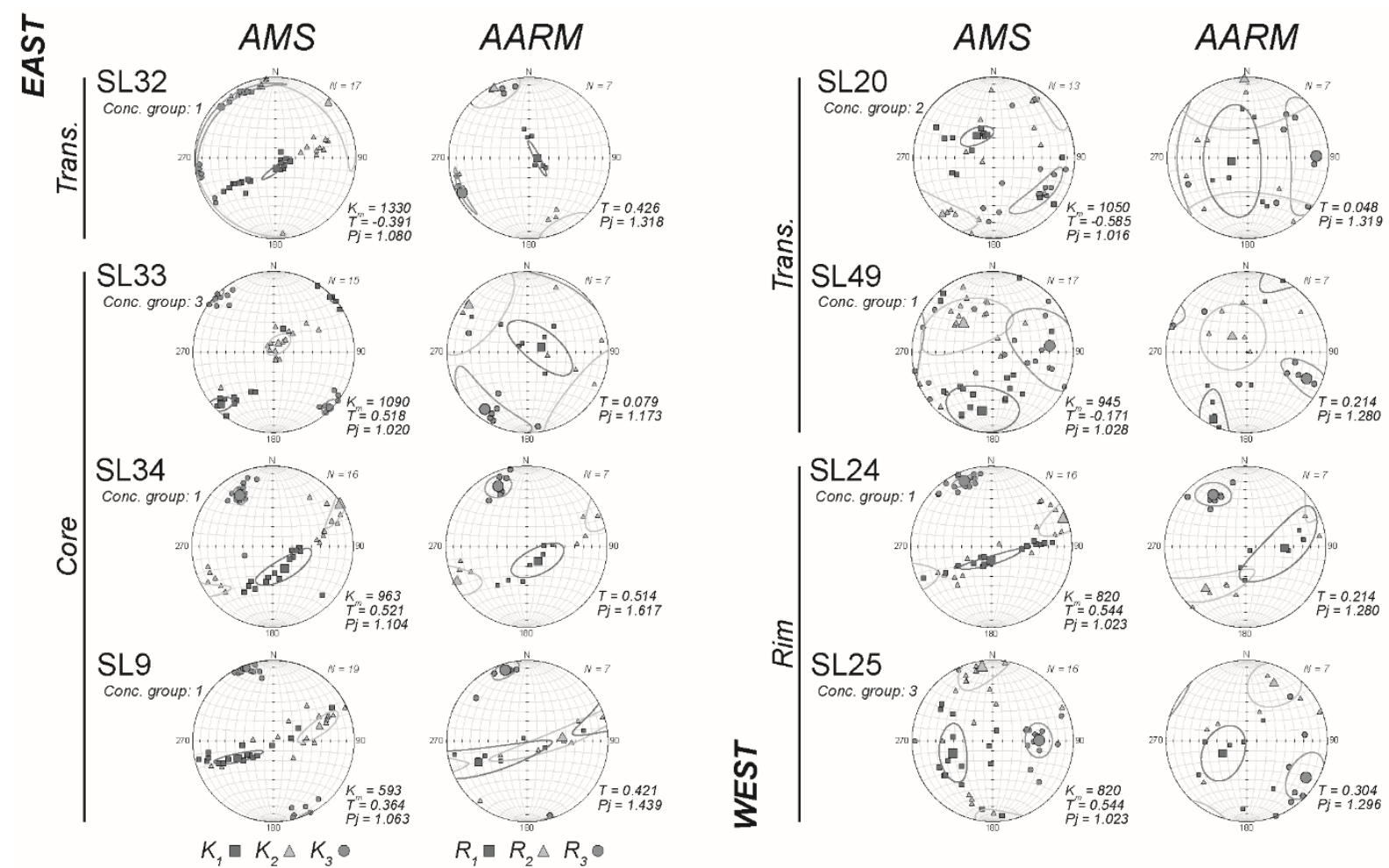

Fig. 11: Examples of AMS and AARM orientation data for sites SL32, SL33, SL9 and SL20 (equal area, lower hemisphere projection). Site averaged $K_{m}, T$ and $P j$ values are reported as well as the concordant group between AMS and AARM orientations (1: concordant; 2: poorly defined but concordant; 3: discordant). Magnetic parameters are calculated using the method of Jelinek (1978). Full dataset available as supplementary material. Location of sites on Fig. 2C. 


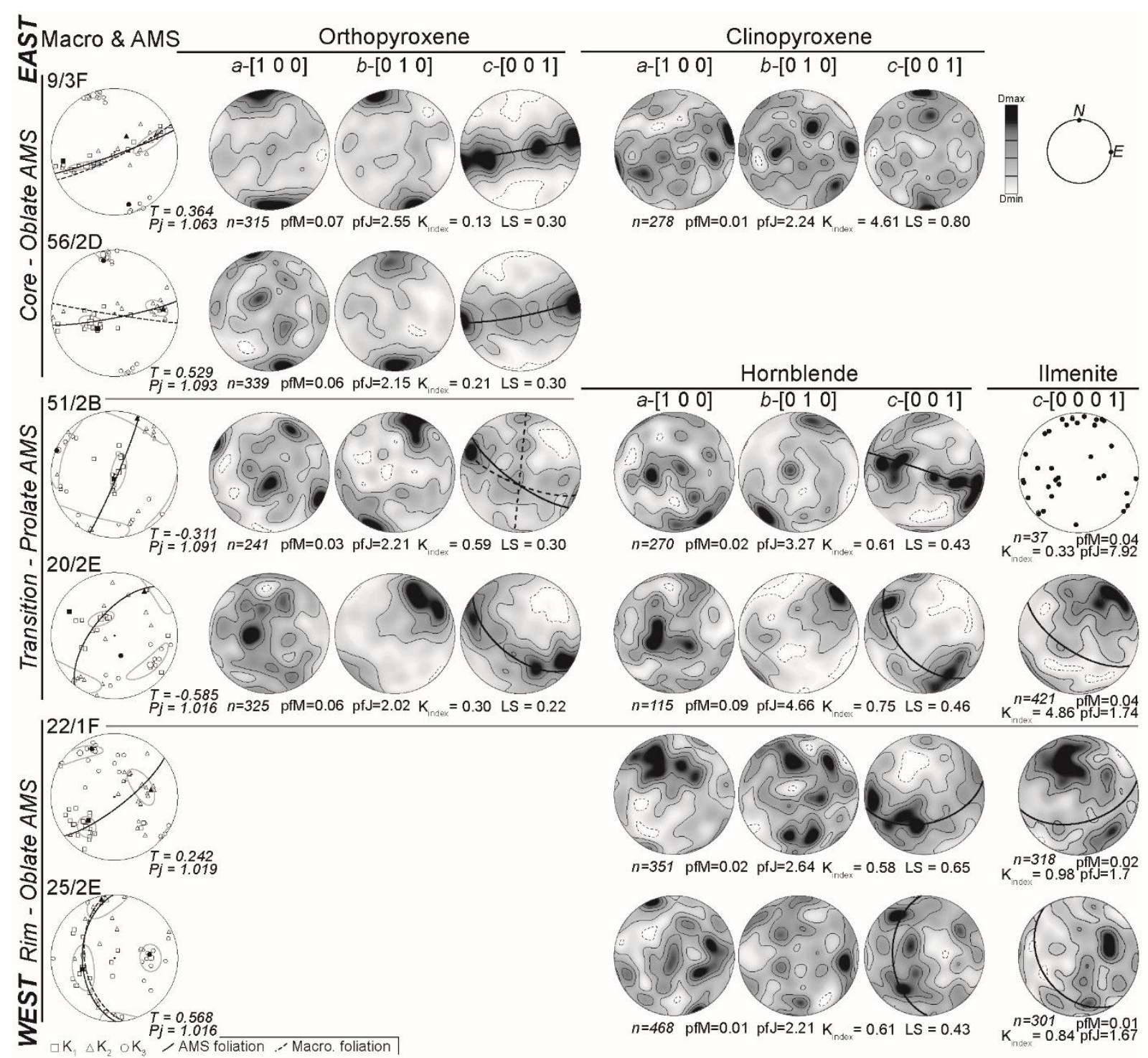

Fig. 12: Pole figures presenting AMS data, macroscopic foliation and CPO obtained by EBSD analysis for six specimens out of 6 drill sites from the core to the rim of the pluton in geographic reference frame (equal area, lower hemisphere projection). AMS and macroscopic data for each site (white symbols) and sample (black symbols) are presented. Orientation Distribution Functions (ODFs) were calculated only for samples with more than 100 analyses; contours indicate the mean uniform density (m.u.d.). Density values are reported in supplementary figure S9. Pole to mean foliations defined by the perpendicular to the $c$-axis mean orientations for orthopyroxene and hornblende and by the $c$-axis mean orientations for ilmenite are presented (solid line: calculated; dotted line: estimated). Location of sites is indicated on Fig. 2C. See text and supplementary material for details and indexes definitions. 


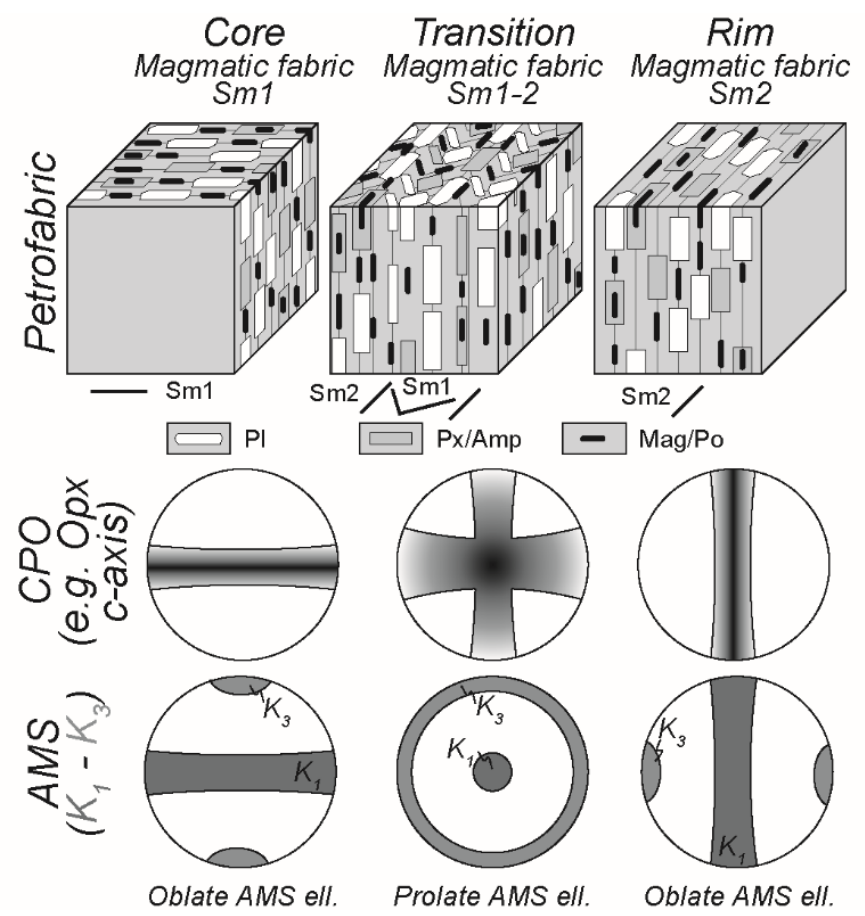

Fig. 13: Idealized sketches of development of magmatic fabrics in the core ( $\mathrm{Sm} 1)$ and the rim (Sm2) of the pluton, their overprinting relationship in the transition zone and the resulting AMS fabric. See text for details.

\section{A Stage 1 Diking $\sim 289-288 \mathrm{Ma}$}
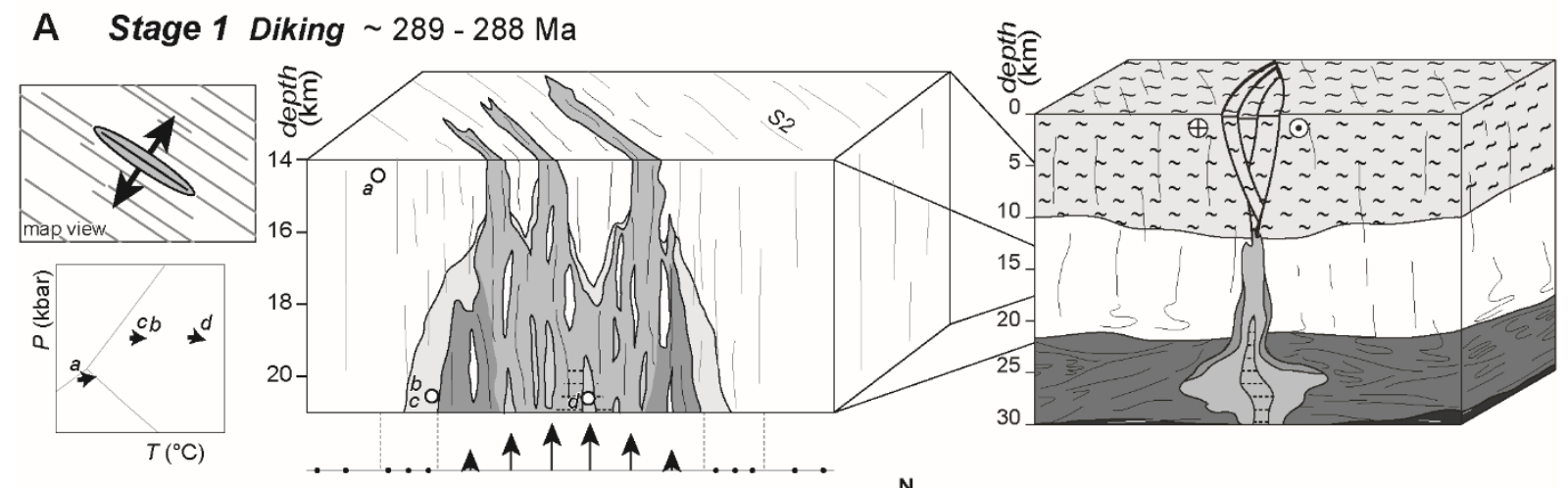

B Stage 2 «Diapirism» $\sim 288-285 \mathrm{Ma}$

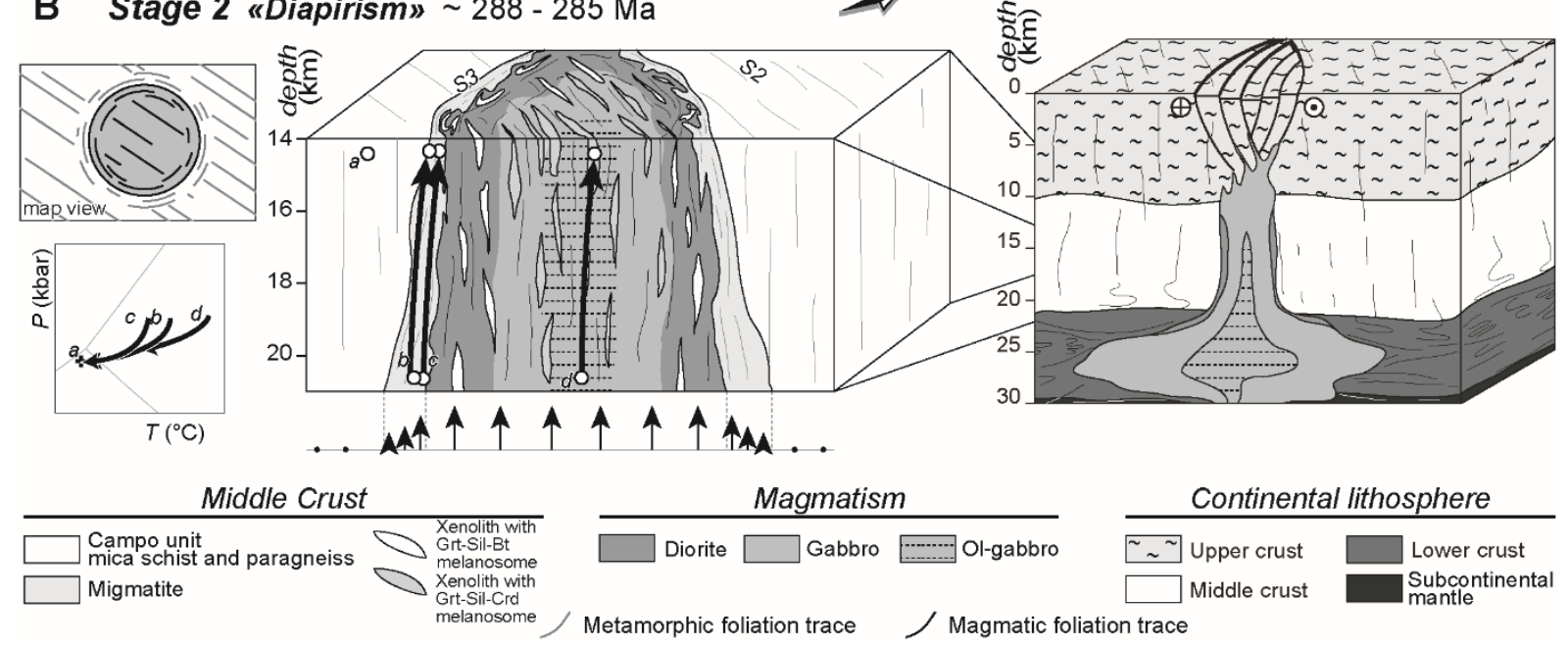

Fig. 14: Evolutionary model depicting the emplacement mechanism during the multi-stage intrusion of the Sondalo gabbro. (A) Fracture-controlled magma ascent and (B) en-masse ascent 
of the core. Insets illustrate the $P-T$ evolution of metasediments (see Petri et al., 2016) and map view synthetic model. See text for details.

\section{SUPPLEMENTARY MATERIAL}

Text S1. Anisotropy of magnetic susceptibility methods

Table S2. Anisotropy of Magnetic Susceptibility data table

Figure S3. Anisotropy of Magnetic Susceptibility stereonet plots

Text S4. Anisotropy of Anhysteretic Remanent Magnetization methods

Table S5. Anisotropy of Anhysteretic Remanent Magnetization data table

Figure S6. Anisotropy of Anhysteretic Remanent Magnetization stereonet plots

Text S7. Crystallographic Preferred Orientation methods

Figure S8. Crystallographic Preferred Orientation shape parameters

Figure S9. Crystallographic Preferred Orientation patterns in AMS axes reference frame 